\title{
Overdoing Gender: A Test of the Masculine Overcompensation Thesis ${ }^{1}$
}

\author{
Robb Willer \\ University of California, Berkeley \\ Christabel L. Rogalin \\ Purdue University, North Central
}

\author{
Bridget Conlon \\ California State University, Fresno \\ Michael T. Wojnowicz \\ University of Washington
}

The masculine overcompensation thesis asserts that men react to masculinity threats with extreme demonstrations of masculinity, a proposition tested here across four studies. In study 1 , men and women were randomly given feedback suggesting they were either masculine or feminine. Women showed no effects when told they were masculine; however, men given feedback suggesting they were feminine expressed more support for war, homophobic attitudes, and interest in purchasing an SUV. Study 2 found that threatened men expressed greater support for, and desire to advance in, dominance hierarchies. Study 3 showed in a large-scale survey on a diverse sample that men who reported that social changes threatened the status of men also reported more homophopic and prodominance attitudes, support for war, and belief in male superiority. Finally, study 4 found that higher testosterone men showed stronger reactions to masculinity threats than those lower in testosterone. Together, these results support the masculine overcompensation thesis, show how it can shape political and cultural attitudes, and identify a hormonal factor influencing the effect.

\section{INTRODUCTION}

The 1964 film Dr. Strangelove, or How I Learned to Stop Worrying and Love the Bomb depicts the initiation of World War III as a great act of over-

${ }^{1}$ We thank Stephen Benard, Nora Broege, Dana Carney, Shelley Correll, Matthew Feinberg, Claude Fischer, Amal Harrati, Michael Hout, Ted Nordhaus, Andrew Penner, Ol- 
compensation by a sexually impotent general. This line of reasoning is not unusual, appearing not only in popular but also academic (e.g., Adler [1910] 1956) discourse. Masculine overcompensation is invoked as an explanation for a variety of behaviors from the everyday - men purportedly purchasing sports cars at the onset of "midlife crises" — to the world-changing — as in analyses of Lyndon Johnson's escalation of the Vietnam War (Fasteau 1974; Kimmel 1996).

The masculine overcompensation thesis asserts that men react to masculine insecurity by enacting extreme demonstrations of their masculinity. Men's pursuit of masculinity in the face of threats is driven by desires to recover masculine status both in their own and others' eyes. The overcompensation dynamic is different from mere compensation. Where compensation would lead men to behave roughly as they would normally, their behavior apparently unaffected by the threat, overcompensation suggests a dynamic of relatively extreme reaction, over and above men's behavior in the absence of threats. In this way, men may inadvertently reveal feelings of threat by behaving in a more extremely masculine way than they otherwise would. If true, the thesis implies that extreme, caricatured demonstrations of masculinity among men may in fact serve as tell-tale signs of underlying insecurity, not self-assured confidence. Those men who exhibit the most masculine traits may actually be seeking cover for lurking insecurities, their outsized masculine displays in fact strategic claims at masculine status, efforts to pass as something they fear they are not.

But while the logic is familiar- the notion that people would act to cover up their self-perceived deficits is often cited in settings beyond gender identity (e.g., Willer, Kuwabara, and Macy 2009) — it is not known whether the claim is valid. Do men overcompensate in response to gender identity threats? In this article we review the theoretical bases for the masculine overcompensation thesis, establishing the theoretical claims underlying the dynamic. We then test the idea of masculine overcompensation in a series of laboratory experiments and a large-scale survey. Finally, we conclude by discussing implications of our research.

\section{THEORY}

The theoretical roots of the masculine overcompensation thesis lie in psychoanalytic theory, specifically Adler's notion that men engage in "masculine protest" as a response to feelings of inferiority ([1910] 1956). Masculine

iver Schultheiss, Michael Shellenberger, the AJS reviewers, and the members of Cornell University's Laboratory Experimental Group for contributions to this article. Direct correspondence to Robb Willer, Department of Sociology, University of California, Berkeley, California 94720. E-mail: Willer@berkeley.edu 
overcompensation also derives from Freud's notion of "reaction formation" ([1898] 1962), which describes the tendency of individuals to respond to the suggestion that they possess a socially unacceptable trait by enacting its opposite, often in the extreme. While empirical support for psychoanalytic theory in general - and Freud's defense mechanisms in particular-is decidedly spotty, research is generally supportive of reaction formation (Baumeister, Dale, and Sommer 1998).

In perhaps the best-known empirical demonstration of reaction formation, one study found that more homophobic men actually showed greater sexual arousal (as indicated by penile circumference measured via a penile plethysmograph) than less homophobic men when watching videos of homosexual intercourse, though they reported lower levels of arousal (Adams, Wright, and Lohr 1996). This finding suggests that homophobia may be a case of reaction formation for men with same-sex attraction and strong concerns about the social implications of being seen as gay (see also Weinstein et al. 2012). The masculine overcompensation thesis follows a similar line of reasoning: men who fear they have insufficient masculinity overcompensate by enacting extreme masculine behaviors and attitudes designed to create the impression that they are quite masculine.

Here we review two additional lines of theory that together provide a theoretical basis for the masculine overcompensation thesis. First, masculinity theory, which argues that masculinity is both more narrowly defined (making masculinity more easily threatened) and socially valued (making men more motivated to recover it) than femininity. Second, theories of identity, which argue that individuals tend to react to feedback that threatens valued identities with overcompensation, enacting attitudes and behaviors associated with the identity to a more extreme extent than they would have in the absence of threats.

\section{Masculinity Theory}

Masculinity theorists have traditionally argued that, while definitions of masculinity vary across contexts, within a given culture men are typically measured against a monolithic standard of "hegemonic masculinity" (Connell 1983). Hegemonic masculinity describes the most legitimate and respected conception of masculinity in a given culture, prescribing a particular set of behaviors and traits that are viewed as most socially desirable in men (Carrigan, Connell, and Lee 1985; Connell 1987). Because femininity and other masculinities are less valued and respected than hegemonic masculinity, the stakes associated with maintaining a masculine identity that hews closely to this ideal are relatively high for men. While the specific characteristics of hegemonic masculinity vary across groups and con- 
texts (Connell and Messerschmidt 2005), several aspects are common (Schrock and Schwalbe 2009), including competitiveness, assertiveness, physical strength, aggression, risk-taking, courage, heterosexuality, and lack of feminine traits. Researchers have emphasized that dominance and control are central to hegemonic masculinity in the American context (Johnson 2005).

In recent years, some masculinity researchers have turned their attention to the changing definition of masculinity in American culture and to an expansion of what are viewed as acceptable masculine attitudes and behaviors (e.g., Anderson 2009). But despite this work most agree that the cultural definition of what are acceptable and respected traits is narrower for masculinity than for femininity (e.g., Schrock and Schwalbe 2009). For example, within the literature on children and adolescents, it is clear that while cultural expectations for girls have shown a remarkable transformation in recent years, moving toward acceptance of expressions of self typically associated with masculinity (Adams and Bettis 2003), there is a much more halting cultural acceptance of behaviors associated with femininity in boys (Kimmel and Mahler 2003; Pascoe 2005).

Masculinity theorists emphasize that sensitivity and responsiveness to masculinity threats are common in men (e.g., Kimmel 1994). The social pressure to maintain an esteemed masculine gender identity is strong, though it is different from other forms of normative pressure in that total conformity is likely impossible. Indeed, the standards of true masculinity are so exacting as to be virtually unattainable, leading men to continually strive to satisfy them (Connell 1987, 1995). As a result, though certain circumstances may be more emasculating than others, the feeling that one is insufficiently masculine is far from an occasional event. Instead, insecurity, feelings of emasculation, and the suspicion of inadequate masculinity are ubiquitous for men. These concerns and feelings of deficiency instigate the enactment of masculinity in everyday life. Because true masculinity is narrowly defined, esteemed, and unattainable, a strain always exists, and the result of that strain is overcompensation and the continual striving for ever greater masculinity.

Kimmel emphasizes the role of men as a sort of "gender police," describing homophobia as the fear among men that other men will detect their insufficient masculinity (1994). This fear, however, is itself a source of shame and must be covered up, along with any possible feminine or inadequately masculine characteristics, ideally with bold demonstrations of strength and masculinity: "What we call masculinity is often a hedge against being revealed as a fraud, an exaggerated set of activities that keep others from seeing through us, and a frenzied effort to keep at bay those fears within ourselves ... the reigning definition of masculinity is a defensive effort to prevent being emasculated" (Kimmel 1994, p. 103). 
Empirical research across a variety of cultures supports the view that masculinity is not easily attained but rather must be continually pursued in the face of threats and challenges (Gilmore 1990). Social psychology research on "precarious manhood" supports this view of men as plagued by chronic doubts (Bosson et al. 2009). In one study researchers found that student participants were able to spontaneously report numerous ways that a man could lose his masculinity (e.g., losing his job) but relatively fewer ways that women could lose femininity (Vandello et al. 2008). Thus, people find it intuitive that men's masculine status is tenuous and easily undermined but do not view femininity in the same way.

One reason that masculinity is easily threatened is that masculine status is relative and hierarchical (Kimmel 1994). Thus, as one man establishes his masculine standing, he necessarily diminishes the standing of other men. Indeed, one way to establish one's own masculinity is by insulting that of another man, creating a self-reinforcing dynamic in which men feed the social pressure that compelled their own masculinity striving in the first place. Thus, masculine insecurity may be in a sense contagious, as it creates in men the seeds of its own perpetuation.

Past research on gender and masculinity in the field and laboratory highlights men's sensitivity to threats. For example, Macmillan and Gartner found that employed wives of unemployed husbands face a greater risk of domestic abuse, perhaps because their employment constitutes a threat to the masculinity of their spouse (1999), a finding also shown for relative spousal income levels (McCloskey 1996). Further, men who are more economically dependent on their wives tend to do less housework (Brines 1994; but see also Bittman et al. 2003), perhaps acting to distance themselves from behaviors seen as feminine. In one experimental study, social psychologists found that men whose masculinity was threatened via bogus feedback on a gender identity survey were more likely to subsequently sexually harass a female participant in the study (Maass et al. 2003). This body of research supports masculinity theorists' contention that men are highly attentive to their masculine status, responding to threats by enacting behaviors associated with masculinity, including aggression and violence.

From this literature we cull two main theoretical claims: (1) a narrower definition exists for what are acceptable and respected masculine traits, as opposed to feminine traits, and (2) masculinity tends to be more respected than femininity (e.g., Ridgeway 2011). Together, these dynamics lead men to be both vulnerable to masculinity threats, due to the narrow definition of masculinity, and motivated to reclaim a masculine gender identity, due to the prestige attached to it. This is not to say that social expectations do not also compel women to "do gender" (West and Zimmerman 1987; Butler 1990; Bordo 1993), and indeed researchers have argued that a corre- 
sponding ideal of "hegemonic femininity" exists (e.g., Ussher 1997; Krane et al. 2004) and that women sometimes strive to reestablish their femininity in the face of threats (Griffin 1998; Munsch and Willer 2012). But we argue here that women should be less readily threatened by feedback suggesting they lack femininity and less motivated to reclaim a feminine identity. Thus, in the current investigation we expect stronger reactions to gender identity threats among men than among women. We return in the General Discussion section to the issue of feminine overcompensation and under what conditions we expect that it would be most likely.

\section{Theories of Identity}

The above theoretical reasoning clarifies why we expect greater responsiveness to gender identity threats in men than in women, but it does not explain why we predict that men will overcompensate in the face of such threats. We draw upon theories of identity for a characterization of how individuals recover valued identities in the face of disconfirming feedback. Identity theorists argue that people strive to maintain identities that are deeply held (Burke and Tully 1977; McCall and Simmons 1978; Stets and Burke 2000b) and socially esteemed (Cialdini et al. 1976). Identity theorists often posit a hierarchy of identities of varying strength (e.g., Stryker 1980), asserting that people are more motivated to act in ways that maintain strongly held and fundamental identities.

Identity theories offer insight on how individuals enact and maintain valued identities in the course of interaction. For example, identity control theory (Burke 2004) proposes a cybernetic model of the relationships between self-concept, behavior, and situational feedback. In the model, individuals receive information that is relevant to a given, salient identity and assess whether this feedback is consistent with the identity. When discrepancies are detected, they behave in ways designed to bring situational feedback in line with their identity standard. Importantly, many theories of identity would predict that when people receive social feedback that is not consistent with a given identity standard, they will enact more extreme versions of behaviors associated with that identity (Burke 1991; Heise 2007; Burke and Stets 2009). Importantly, under such conditions individuals are expected not merely to compensate but to overcompensate in an effort to recover the identity.

For example, if a person assuming a role (e.g., mother, athlete) strongly associated with some characteristic (e.g., warmth, competitiveness) received feedback that she or he failed to convey this trait in interaction (e.g., behaving coldly or passively), that person would be likely to enact an extreme form of the characteristic in an effort to restore an average presen- 
tation of self closer to the desired level. This view of identity maintenance is akin to the workings of a thermostat, which does not maintain a steady temperature but instead starts heating cycles that lift a room's temperature beyond the desired level upon receiving feedback that the temperature has fallen too far below its target. Thus, individuals responding to feedback that they have fallen short of expectations associated with a valued selfconcept are expected to go beyond prototypical behaviors associated with the identity, acting in ways that are extreme versions of the identity in order to reclaim it. Nonetheless, such a response can be self-defeating as the feelings of inadequacy motivating the response are detectable in the extremity of the individual's reaction.

In research on identity processes, gender identification as masculine or feminine drives gender-relevant behaviors, such as men who identify as highly masculine behaving in a more dominant or competitive fashion (Burke 1989; Stets and Burke 2000a). Gender identities are thought to typically be strongly held (Burke and Tully 1977). Further, other research on identity maintenance finds that individuals are more motivated to maintain identities that are highly socially valued (Cialdini et al. 1976). As a result, we would expect men to be strongly driven to recover a masculine gender identity when faced with situational feedback suggesting they lack masculinity, more than we would expect women to strive to recover femininity. Further, men's behavior in the face of threat should not simply be compensatory, but rather overcompensatory. In an effort to project an overall impression of sufficient masculinity for themselves and others, men should enact extreme masculine behaviors when they receive feedback suggesting a lack of masculinity.

\section{Testosterone and Masculinity}

A mounting body of physiological research has explored relationships between levels of the steroid hormone testosterone and a variety of social behaviors in humans. Most notably for the present investigation, several studies have linked testosterone levels with masculine behaviors and attitudes related to dominance, aggression, power, risk-taking, and competitiveness (e.g., Mazur and Booth 1998; Booth et al. 2006; Carney, Cuddy, and Yap 2010). Most relevant to the present investigation, past research finds that testosterone levels are associated with (1) sensitivity to threats and status standing (van Honk et al. 1999; Josephs et al. 2006; Terburg, Aarts, and van Honk 2012) and (2) the enactment of dominance behaviors (Mazur and Booth 1998; Mehta, Jones, and Josephs 2008). This body of work and the fact that testosterone levels are typically found at significantly higher levels in men than women suggest the possibility that testosterone levels might play a role in masculine overcompensation. 
But how exactly might testosterone levels and overcompensation be linked? Research on testosterone and masculine-typed behaviors like aggression and dominance has typically failed to find consistent main effects of testosterone levels on behavior (Rowe et al. 2004; Archer 2006), suggesting that the link between testosterone and behavior is more nuanced than often assumed (Booth et al. 2006). Most research supports the view that testosterone plays a complex role in influencing traits and behaviors associated with masculinity, both in general and in the specific domain of men's responses to threats and challenges (Kemper 1990; Josephs et al. 2006).

One possibility is that men's testosterone levels might mediate the overcompensation effect. It could be that testosterone increases when men are faced with a masculinity threat and these higher levels in turn lead to more masculine behaviors. This possibility is consistent with research on the "challenge hypothesis." Originally developed to explain the role of testosterone in nonhuman animals (Wingfield et al. 1990), applied to humans the hypothesis argues that threatened men will exhibit increased testosterone levels, which in turn leads to higher levels of aggression and dominance (Archer 2006; Trumble et al. 2012). Consistent with this, Cohen et al. (1996) found that men who were bumped and insulted in a laboratory experiment showed significant testosterone increases and more aggressive behavior, especially if they were from the American South, where the researchers argue such actions are culturally understood to be more threatening to a man's standing.

A more likely alternative is that testosterone levels could moderate the masculine overcompensation effect. It could be the case, for example, that men with higher basal testosterone levels are more responsive to masculinity threats. This is suggested by research on "the mismatch effect," which shows that higher-testosterone men are more concerned with their status and dominance and more sensitive to threats to their standing (Newman, Sellers, and Josephs 2005; Josephs et al. 2006). For example, research has found that higher-testosterone individuals look longer at pictures of threatening faces than those with lower testosterone (van Honk et al. 1999). Further, studies show that when the status of higher-testosterone individuals is challenged, they react with emotional arousal, increased heart rate, and greater focus on status and power concerns (Josephs et al. 2003; Josephs et al. 2006). Taken together, these findings suggest the possibility that masculine overcompensation is more pronounced among higher-testosterone men.

\section{PRESENT RESEARCH}

The above-reviewed theory and research suggests the plausibility of our central claim. On the one hand, masculinity theorists argue that masculinity 
is both narrowly defined and highly socially valued, making men relatively more likely to perceive threats to their masculinity and more motivated to respond to them. Theories of identity explain how individuals strive to maintain deeply held and socially valued identities like masculinity, positing that such identities are maintained via an overcompensation dynamic in which individuals respond to threats with extreme forms of identityconsistent attitudes and behavior. Finally, research has linked testosterone levels with responsiveness to threats and the enactment of masculine traits like dominance, though it remains an open question whether testosterone levels might mediate or moderate the masculine overcompensation dynamic.

Based on the above, we hypothesize that men will react to masculinity threats with extreme demonstrations of masculinity but that women will be far less affected by corresponding threats to their femininity. We test this claim across a series of studies. Study 1 is a laboratory experiment in which we tested whether men whose masculinity was threatened would adopt more masculine attitudes. In study 2 we conducted another laboratory experiment in an effort to identify what aspect of masculinity men enact through overcompensation. Study 3 tests the masculine overcompensation thesis in a more diverse sample, using a national survey to examine whether men who report greater feelings that social changes threaten the status of men also tend to espouse more masculine attitudes. In each of these studies, we also test for possible effects for women. Finally, in study 4 we returned to a laboratory setting to explore the possible mediating or moderating role that men's testosterone levels might play in the overcompensation process.

\section{STUDY 1: AN EXPERIMENTAL TEST}

We conducted a laboratory experiment as an initial test of the masculine overcompensation thesis. In the study we administered a gender identity survey to men and women and then gave them randomly determined feedback indicating that they had scored in either the "masculine" or "feminine" range relative to past study participants. We then looked at how this feedback might affect their responses on subsequent surveys. Specifically we measured participants' support for the Iraq War, views of homosexuality, and interest in purchasing a sport utility vehicle (SUV), all views that were considered masculine in the study population. ${ }^{2}$ Based on the above theoret-

\footnotetext{
${ }^{2}$ Past theory and research have linked masculinity with support for war (Connell 1985; Christensen and Ferree 2008; Messerschmidt 2010), homophobia (Kimmel 1994), and SUV ownership (Bradsher 2002). Conceptions of masculinity, however, vary across
} 
ical reasoning, we expect men whose masculinity is threatened to express more support for the Iraq War, more negative views of homosexuality, and more interest in buying an SUV. While we predict effects of masculinity threats but weak or no effects for femininity threats among women, we include women in our study to establish that our predicted effects are in fact unique to men. That said, because the dependent measures we employ are selected to capture masculine attitudes, this study offers limited insight on whether and when women would exhibit overcompensation.

\section{Method}

Design and Participants. - The study features a 2 (participants were men/ women $) \times 2$ (participants' gender identity was threatened/not) experimental design. One hundred and eleven undergraduate students (60 women, 51 men) at Cornell University participated in the study for pay plus the option of extra credit in a sociology class. One participant was excluded from analysis because he reported suspicion regarding the gender identity feedback.

Procedure.-Participants were recruited by fliers advertising payment for participation in a sociology experiment or by announcements in their undergraduate sociology class. After reporting to the lab, participants filled out a demographic questionnaire and a "gender identity survey," the text of which is given in the appendix. The gender identity survey was the Bem Sex Role Inventory, a battery that asks respondents to indicate how well a series of adjectives (e.g., competitive, soft-spoken) describes their personality (Bem 1974). After this the participants were asked to wait several minutes while the research assistant ostensibly scored the survey. Participants were given results on their gender identity in a sealed envelope with their name printed on it. Envelopes were filled with feedback sheets prior to the session and sealed so that research assistants would be unaware of the experimental condition.

Feedback sheets displayed a 0-50 scale of possible scores on the gender identity survey, as shown in figure 1 . The range from 0 to 25 was the masculine half of the scale and from 26 to 50 the feminine half. In the middle of each range, brackets indicated the "average male range" and "average female range" for scores in the study. In actuality, the average ranges given

groups (Connell and Messerschmidt 2005), thus we conducted a pretest $(N=60)$ in a separate sample to assess whether these dependent variables were viewed as masculine among members of the population. Participants rated Iraq War support, negative views of homosexuality, and SUV ownership to be more masculine than they were feminine $(P$ 's $<.001)$ and more masculine than opposing war, having positive views of homosexuality, or owning one of the other three vehicles tested $\left(P^{\prime} \mathrm{s}<.05\right)$. 
American Journal of Sociology

\section{Gender Identity Survey Feedback}

The following is your score on the gender identity survey. It has been placed on a 0 to 50 index running from "Masculine" to "Feminine." Those lower on the scale have more masculine gender identities, those higher on the scale have more feminine gender identities.

Your Score:

Below is a line graph of average score for men and women on the Gender Identity Survey. We have indicated your score with an " $\mathrm{X}$ " on the line.

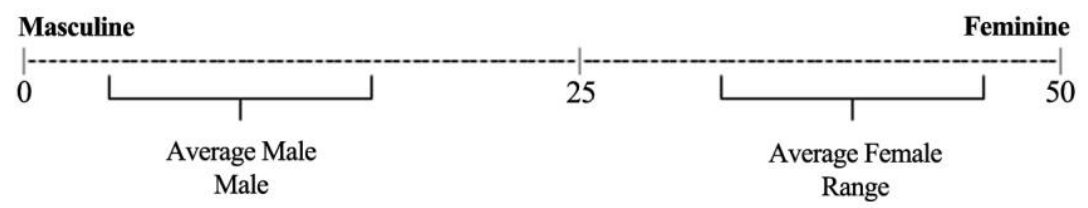

FIG. 1.-Format for gender identity feedback provided to participants

on the feedback sheets, as well as the participants' scores, were false and created purely for the purposes of manipulating gender identity feedback. ${ }^{3}$

Men and women in the study were randomly assigned to receive either masculine or feminine feedback. Half of men were told they scored an " 11 " on the gender identity survey, a score corresponding to the middle of the masculine distribution noted on the feedback sheets, while the other half were given a score of " 32 ," just inside the feminine range of the scale. Half of the women in the study were told that they scored a "39" on the gender identity survey, corresponding to the middle of the feminine distribution, while the other half were told they scored an "18," a number just within the typical masculine range of the scale.

Dependent measures. - Participants were next asked to fill out two survey packets. One was a Political Views Survey and assessed participants' attitudes toward homosexuality and the Iraq War, in addition to a variety of filler items. Participants rated on 7-point scales their support for a constitutional amendment banning same-sex marriage, the gay rights movement (reverse-scaled), and whether they thought homosexuality was "always" or "never wrong." These three measures were averaged to form a composite

${ }^{3}$ This notion that masculinity and femininity lie at two ends of a single spectrum of gender identity is inconsistent with much of the gender literature and with the actual scoring of the Bem Sex Role Inventory. Nonetheless, pilot testing indicated that participants generally viewed this feedback as highly credible and consistent with their own view of gender identity. 
measure of negative attitudes toward homosexuality (Cronbach's $\alpha=.89$ ). Participants also rated on 7-point scales their support for "President Bush's decision to invade Iraq" and approval of "President Bush's handling of the war in Iraq." These two items were averaged to form a composite measure of support for the Iraq War (Cronbach's $\alpha=.93$ ). The political views survey also included a standard measure of positive and negative affect (the PANAS), asking participants to indicate on a 5-point scale how much each of 20 emotions items described their feelings at the time (Watson, Clark, and Tellegen 1988).

Participants also filled out a Car Purchasing Survey, which included one-page descriptions of four different Ford automobiles (an SUV, a minivan, a sedan, and a coupe), including pictures, engine specifications, and fuel economy information. Participants were asked to carefully examine each vehicle's description before filling out a survey on the back page assessing attitudes toward each vehicle. Participants indicated on a 10-point scale how "desirable" each vehicle was, how much they would be willing to pay for each one, and which they would be most likely to buy. The order in which participants completed the political views and car purchasing surveys was randomized. Finally, participants were sensitively debriefed regarding the deceptive gender identity feedback, thanked for their participation, and paid. Debriefing carefully followed procedures developed for studies involving false feedback (Ross, Lepper, and Hubbard 1975; Aronson et al. 1990).

\section{Results}

Table 1 gives means for men's and women's attitudes toward the Iraq War and homosexuality. Ratings are mostly low relative to each composite scale's midpoint of "4," suggesting that participants reported generally positive views of homosexuality and low support for war. Turning to our predictions, we find that men whose masculinity was threatened reported significantly greater support for the Iraq War and more negative views of homosexuality than did men in the study whose masculinity was not threatened $(P$ 's $<.05)$. Women, however, showed no significant differences across conditions in their reported attitudes.

Turning to our predictions regarding vehicle preferences, men whose masculinity was threatened reported viewing the SUV as more desirable and reported being willing to spend more money to purchase it than did unthreatened men. On average, men whose masculinity was threatened reported a willingness to pay $\$ 7,320$ more for the SUV than did men whose masculinity was not. There were no significant differences between threatened and unthreatened men in their ratings of the other three vehicles $(P$ 's $>.25)$. 
American Journal of Sociology

TABLE 1

The Effects of Gender Identity Feedback on Men's and Women's Support for the Iraq War, Views of Homosexuality, and Desire to Purchase an SUV

\begin{tabular}{|c|c|c|c|}
\hline & $\begin{array}{c}\text { Gender Identity } \\
\text { Threatened } \\
\text { (Mean) }\end{array}$ & $\begin{array}{c}\text { Gender Identity } \\
\text { Not Threatened } \\
(\text { Mean })\end{array}$ & $t$ \\
\hline \multicolumn{4}{|l|}{$\operatorname{Men}(N=51)$ : } \\
\hline Support for Iraq War . . . . . . . . . & $\begin{array}{c}3.64 \\
(1.85)\end{array}$ & $\begin{array}{c}2.65 \\
(1.52)\end{array}$ & $2.06 *$ \\
\hline Negative views of homosexuality . . . & $\begin{array}{c}4.03 \\
(1.68)\end{array}$ & $\begin{array}{c}2.77 \\
(1.60)\end{array}$ & $2.70 * *$ \\
\hline SUV desirability $\ldots \ldots \ldots \ldots \ldots \ldots$ & $\begin{array}{c}6.56 \\
(2.63)\end{array}$ & $\begin{array}{c}4.84 \\
(3.16)\end{array}$ & $2.09 *$ \\
\hline SUV pay (in thousands of dollars) ... & $\begin{array}{c}28.00 \\
(13.76)\end{array}$ & $\begin{array}{c}20.68 \\
(10.63)\end{array}$ & $2.10 *$ \\
\hline \multicolumn{4}{|l|}{ Women $(N=60)$ : } \\
\hline Support for Iraq War . . . . . . . . . & $\begin{array}{c}2.52 \\
(1.59)\end{array}$ & $\begin{array}{c}2.40 \\
(1.39)\end{array}$ & .30 \\
\hline Negative views of homosexuality . . . & $\begin{array}{c}2.54 \\
(1.81)\end{array}$ & $\begin{array}{c}2.20 \\
(1.52)\end{array}$ & .80 \\
\hline SUV desirability $\ldots \ldots \ldots \ldots \ldots \ldots$ & $\begin{array}{c}5.20 \\
(3.03)\end{array}$ & $\begin{array}{c}5.17 \\
(2.74)\end{array}$ & .05 \\
\hline SUV pay (in thousands of dollars) ... & $\begin{array}{l}22.52 \\
(14.6)\end{array}$ & $\begin{array}{c}25.38 \\
(19.52)\end{array}$ & .63 \\
\hline
\end{tabular}

Note.-SDs are in parentheses.

$* P<.05$.

$* * P<.01$.

Women showed no significant differences across conditions in how desirable they felt any of the vehicles were, nor in how much they were willing to pay for them. Finally, a higher proportion of threatened men (40\%) than unthreatened men (16\%) reported being most likely to buy the SUV from among the four vehicles $\left(\chi^{2}(1)=.3 .57, P=.059\right)$; however, we found no difference between threatened (17\%) and unthreatened women $(17 \%)$.

We also explored participants' reported emotions. These analyses were largely exploratory. One could imagine that men whose masculinity was threatened might report greater negative affect. Alternatively, threatened men might express lower levels of emotions in general in effort to appear more masculine. Results supported the former prediction as threatened men reported feeling more guilty, ashamed, upset, and hostile than unthreatened men $(P$ 's $<.05)$. Women showed no differences across conditions with one exception; women given feedback that they were masculine reported feeling higher levels of nervousness than women who were told they were feminine $(P<.03){ }^{4}$

\footnotetext{
${ }^{4}$ One would expect one of the 20 items to be significant by chance using a .05 significance
} standard. 


\section{Discussion}

Results of study 1 support the masculine overcompensation thesis. As predicted, men whose masculinity was threatened expressed more masculine attitudes than did men whose masculinity was not. Threatened men reported greater support for war, more negative views of homosexuality, and greater interest in purchasing an SUV, all attitudes that a pretest confirmed were viewed as masculine in the study population. Threatened men also reported significantly greater negative affect on multiple emotion survey items. In contrast, women showed no significant effects of the gender identity feedback.

One possible concern regarding the results of this study is that random assignment might have failed to equalize important characteristics across conditions of the study. As one way to test for this concern, we looked at participants' self-reported liberalism as reported on the demographic questionnaire administered before the experimental manipulation. Men reported effectively the same levels of liberalism in the threatened and unthreatened conditions $(t=.87, P=.39)$. If anything, more liberal men were more often assigned to the threat condition, an initial difference that would make the predicted effects for support for war and expressed homophobia less likely. Indeed, in a multivariate analysis of these effects controlling for self-reported liberalism, the effects of threat for men become slightly more statistically significant. Women's reported liberalism also did not differ significantly across conditions $(t=-.26, P=.80)$. We also analyzed participant's scores on the Bem Sex Role Inventory. Masculinity and femininity scores for men and women did not vary across conditions $(P$ 's $>.29)$; nor did they interact with any of the main effects reported here.

Thus, we have evaluated several alternative accounts for the data beside the masculine overcompensation thesis, including the possibilities that (1) men and women react to gender identity threat with extreme gender-typed behaviors, (2) men assigned to the masculinity-threat condition were simply more politically conservative, and (3) men assigned to the masculinity-threat condition were more (or less) masculine (or feminine). In each case we found no support for these alternative explanations.

\section{STUDY 2: MASCULINITY THREATS AND DOMINANCE}

The purpose of study 2 is to develop a more general understanding of what aspect of masculinity men seek to bolster in response to masculinity threats. One possibility suggested by the results of study 1 is that men respond to masculinity threats by seeking to reacquire feelings of dominance and power, core characteristics of masculinity (Kimmel 1994). If so, it is possible that threatened men in study 1 sought to reassert their desire and support for dominance in advocating aggressive military action, subordination of a popula- 
tion perceived as violating traditional gender roles, and expressing a desire to purchase a large, powerful vehicle.

To test this reasoning more directly, we replicated the methodology of study 1 , employing new dependent measures, including a standard measure of desire for dominance and support for dominance hierarchies, "social dominance orientation" (Pratto et al. 1994). Past research suggests that social dominance orientation could be implicated in masculine overcompensation. Dominance attitudes tend to be higher in men than women (Sidanius, Pratto, and Bobo 1996). Men who identify more strongly as men hold stronger dominance attitudes, while the opposite pattern is observed among women (Wilson 2005). Men higher in dominance attitudes are more responsive to masculinity threats (Maass et al. 2003). In turn, dominance attitudes predict support for war and nonegalitarian political attitudes (Sidanius and Pratto 1999).

A secondary purpose of this study is to address a potential alternative explanation for study 1 . One commonality among two of the dependent measures used in our first study - support for the Iraq War and opposition to homosexuality - is that each is related to conservatism in the contemporary United States. Thus, it could be that men whose masculinity was threatened in that study adopted more conservative political attitudes, perhaps because of cultural associations between masculinity and political conservatism (e.g., Ducat 2004). To test this possibility we added multiple surveys tapping aspects of political conservatism as dependent measures.

\section{Method}

Design, participants, and procedure.-The study features a 2 (participants were men/women $) \times 2$ (participants' gender identity was threatened/not) experimental design. One hundred undergraduate students (60 women, 40 men) at Cornell University participated in the study for pay, plus extra credit in a psychology class. Study procedures were identical to study 1 except that participants completed different dependent measures after receiving feedback on their gender identity.

\section{Dependent Measures}

Because it provides an established measure of dominance attitudes, we administered the "group-based dominance" subscale of a standard survey of social dominance orientation (Pratto et al. 1994; Jost and Thompson 2000). Participants indicated their level of agreement on 10-point scales with a series of statements including, "In getting what your group wants, it is sometimes necessary to use force against other groups," "Superior groups should 
dominate inferior groups," and "Inferior groups should stay in their place." Results of this 8-item survey were averaged to form a composite (Cronbach's $\alpha=.78)$.

We also included several measures of political conservatism. First, we asked respondents to indicate on 7-point scales how positively or negatively they felt about a series of political positions: reduced aid to the poor, the U.S. military, higher taxes on the rich (reverse-scaled), government support for business, the death penalty, and affirmative action (reverse-scaled). These items were averaged to form an issue-based, 6-item composite measure of political conservatism (Cronbach's $\alpha=.63$ ). Second, we measured participants' levels of system justification, the belief that the status quo is fundamentally fair, a position strongly associated with political conservatism in past research (Jost, Banaji, and Nosek 2004). Participants indicated on 9-point scales their degree of agreement with a series of statements including, "Everyone has a fair shot at wealth and happiness" and "In general, you find society to be fair." Responses to this 8-item battery (e.g., Kay and Jost 2003) were averaged to create a composite (Cronbach's $\alpha=.78$ ). Finally, we assessed levels of traditionalism, a core aspect of conservative political beliefs (Jost et al. 2003). Participants indicated on 9-point scales their degree of agreement with statements including, "It's better to stick with what you have than to keep trying new uncertain things" and "I need to know that something would really work before I'd be willing to take a chance at it." Their responses to this standard 7-item battery (McClosky 1958) were averaged to form a composite (Cronbach's $\alpha=.64$ ).

\section{Results and Discussion}

Table 2 shows results for men and women given feedback that was either gender identity threatening or unthreatening. First, we find support for our central prediction. Men whose masculinity was threatened did express stronger dominance attitudes than unthreatened men $(P<.04)$. However, there was no effect of gender identity feedback on the reported dominance attitudes of women $(P>.40)$. This finding supports our reasoning that men react to masculinity threats with stronger dominance-related attitudes, in this case reflected in their greater desire for dominance and support for dominance hierarchies in society. This finding suggests that increased desire and support for dominance among threatened men may have driven the results of study 1 .

We found no support, however, for the notion that masculinity threats simply made men more conservative in general. Threatened men did not report more conservative views on a battery measuring attitudes on several political issues, nor greater system justification $(P$ 's $>.25)$. In fact, threat- 
American Journal of Sociology

TABLE 2

The Effects of Gender Identity Feedback on Men's and Women's Dominance Attitudes, Political Conservatism, System Justification, and Traditionalism

\begin{tabular}{|c|c|c|c|}
\hline & $\begin{array}{c}\text { Gender Identity } \\
\text { Threatened (Mean) }\end{array}$ & $\begin{array}{l}\text { Gender Identity Not } \\
\text { Threatened (Mean) }\end{array}$ & $t$ \\
\hline \multicolumn{4}{|l|}{$\operatorname{Men}(N=40)$ : } \\
\hline Dominance attitudes ...... & $\begin{array}{c}4.36 \\
(1.53)\end{array}$ & $\begin{array}{c}3.26 \\
(1.61)\end{array}$ & $2.22 *$ \\
\hline Political conservatism . . . . & $\begin{array}{c}3.77 \\
(1.07)\end{array}$ & $\begin{array}{c}3.41 \\
(.96)\end{array}$ & 1.12 \\
\hline System justification . . . . . . & $\begin{array}{c}5.06 \\
(1.43)\end{array}$ & $\begin{array}{c}5.04 \\
(1.08)\end{array}$ & .05 \\
\hline Traditionalism . . . . . . . & $\begin{array}{c}2.23 \\
(.95)\end{array}$ & $\begin{array}{c}2.96 \\
(1.23)\end{array}$ & $2.11^{*}$ \\
\hline \multicolumn{4}{|l|}{ Women $(N=60)$ : } \\
\hline Dominance attitudes . . . . . . & $\begin{array}{c}2.91 \\
(1.43)\end{array}$ & $\begin{array}{c}2.57 \\
(1.78)\end{array}$ & .80 \\
\hline Political conservatism . . . . . & $\begin{array}{l}3.07 \\
(.73)\end{array}$ & $\begin{array}{l}3.27 \\
(.61)\end{array}$ & 1.15 \\
\hline System justification . . . . . . & $\begin{array}{c}4.45 \\
(1.00)\end{array}$ & $\begin{array}{l}4.55 \\
(.91)\end{array}$ & .41 \\
\hline Traditionalism . . . . . . . & $\begin{array}{c}2.72 \\
(.93)\end{array}$ & $\begin{array}{l}2.65 \\
(.95)\end{array}$ & .31 \\
\hline
\end{tabular}

Note.-SDs are in parentheses.

$* P<.05$.

$* * P<.01$.

ened men reported significantly less traditionalism $(P<.05)$, a result we did not expect. Revisiting the items used to assess this construct, it may have been that men whose masculinity was threatened were disinclined to show deference to the ideas of those who came before them, preferring to go with newer, riskier ideas of their own. If so, this finding could be consistent with the notion that men sought to reclaim masculinity by expressing masculinetyped views associated with strength, power, and dominance. We found no effects of gender identity feedback on women's reported levels of political conservatism, system justification, or traditionalism $(P$ 's $>.25)$.

\section{STUDY 3: CORRELATIONAL ANALYSES IN A DIVERSE SAMPLE}

Studies 1 and 2 demonstrated in laboratory settings that men whose masculinity was threatened reacted with more extreme masculine attitudes, in particular views associated with dominance. These studies were, however, conducted within a relatively small, homogeneous population, creating external validity concerns (e.g., Lieberson 1987; but see also Lucas 2003). While laboratory experiments have several unique advantages, for example, random assignment to controlled conditions sharply reduces spuriousness con- 
cerns, constraining the scope of alternative explanations - the use of demographically homogeneous convenience samples limits confidence in the generality of findings. There may have been something unique to the population studied that partially drove the observed effects; for example, it could be that young men are uniquely sensitive to threats to their masculinity where older men might not be. Indeed, ample masculinity research suggests that the dynamics of masculinity can vary substantially by race, class, and age (Schrock and Schwalbe 2009).

One way to address these concerns would be to look at the correlation between masculinity threat and extreme masculine attitudes in a largescale survey that provides greater demographic heterogeneity. Such a study would offer less certainty that the relationship between the variables was causal, given the threat of spurious and/or reverse causation in correlational research, but it would offer much greater confidence that the findings of studies 1 and 2 are externally valid. Specifically, it would reduce concerns that the results of studies 1 and 2 were driven by the use of a sample that was somehow uniquely vulnerable to masculinity threat. In this way, laboratory experiments and correlational analysis of large-scale surveys involving diverse samples are uniquely complementary methods, as experiments offer leverage on causal inference lacking in correlational research and large-scale surveys on diverse samples offer the external validity lacking in laboratory experiments.

Ideally we would have tested our claims in a large, representative data set, but we were unable to find one with an adequate measure of our central, independent variable: masculinity threat. We were, however, able to partner with a private research firm on the construction of a large-scale survey featuring a diverse sample of Americans, adding to the survey an item gauging perceptions of threat to gender status as well as measures of several of the dependent variables from studies 1 and 2 . While the survey was not nationally representative and is essentially a convenience sample, it does provide substantial sample diversity. If our results are robust in analyses on this data set, it would provide evidence that the results of studies 1 and 2 were not driven by some unique characteristic of the samples used in those studies.

In study 3 we test for relationships between men's reported feelings that social changes threaten the status of men and a variety of masculine-typed attitudes. We anticipate that men's feelings of threat will be related to these attitudes but that there will be no association between feelings of gender threat and the same attitudes among women. In addition to addressing external validity concerns, study 3 is intended to substantively extend the findings of studies 1 and 2. While studies 1 and 2 conceptualized masculinity threat as a situational variable, study 3 posits that perceptions that the status of men in the larger society is declining may also threaten men's 
American Journal of Sociology

masculinity. Theorists have argued that men may be highly responsive to their perception of the macrolevel status of their gender, being threatened by the rise of feminism, the gay rights movement, and other social trends that could challenge men's traditional status advantage (e.g., Kimmel 1996; Schrock and Shwalbe 2009). In addition, laboratory research suggests that men's perception that the status difference between men and women has declined are linked to overcompensatory behaviors, like sexual harassment (e.g., Dall'Ara and Maass 2000; Maass et al. 2003).

Study 3 also extends our study of what masculine-typed attitudes and behaviors can be shaped by feelings of threat. In study 3 we again look at the relationship between gender identity threat and support for the Iraq War, views of homosexuality, and dominance attitudes. We also now look at another attitude - belief in male superiority - that theorists have argued is closely tied to men's maintenance of a masculine gender identity (e.g., Kimmel 1994; Beneke 1997).

\section{Method}

Data from the 2007 American Values Survey (AVS) were acquired from American Environics, a private, California-based research firm. The AVS is a hybrid Internet and mail-based, national survey, conducted every 2-4 years since 1992. It tracks data on an array of values, attitudes, and behaviors over time for commercial and political consulting purposes. Respondents were contacted in six waves from a database of records obtained from Genesys Sampling. The first two waves of recruitment targeted a representative sample of Americans stratified by gender, race, age, and state of residence with a purposeful oversample of California residents. Ensuing waves targeted demographic groups underrepresented in the prior waves. In all approximately $2.7 \%$ of contacted respondents consented to participate, a low response rate by standards of academic research, but less so for research in the private sector (e.g., Putnam 2000). We discuss possible concerns regarding sample selection bias below in the study Discussion. Table 3 gives demographic data on the sample. While diverse, the sample's demographic make-up diverged from the U.S. population in various ways (e.g., older, more white, more college-educated) and thus should not be taken as representative.

Measures.-We used a variety of demographic variables as controls in analysis: gender, race, age, income, and education. Race and ethnicity were controlled for via dummy variables for whether respondents indicated that they were white, African-American, Latino and/or Hispanic, Asian, or "other." Education was controlled for with binary variables for whether the respondent's highest level of education achieved was less than high 
The Masculine Overcompensation Thesis

TABLE 3

Descriptive Statistics on Control Variables for Study 3

\begin{tabular}{|c|c|}
\hline Variable Name & Mean \\
\hline Gender $($ female/male; $\%) \ldots \ldots \ldots \ldots$ & $46.9 / 53.1$ \\
\hline Age $($ years $) \ldots \ldots \ldots \ldots \ldots$ & $\begin{array}{c}50.2 \\
(16.5)\end{array}$ \\
\hline \multicolumn{2}{|l|}{ Race/ethnicity (\%): } \\
\hline White................ & 79.7 \\
\hline Black . . . . . . . . . . . . . & 6.2 \\
\hline Latino/Hispanic . . . . . . . . . . . . & 10.8 \\
\hline$A \operatorname{sian} \ldots \ldots \ldots \ldots \ldots$ & 2.8 \\
\hline 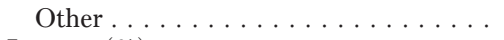 & .5 \\
\hline \multicolumn{2}{|l|}{ Income $(\%)$ : } \\
\hline Less than $\$ 30,000 \ldots \ldots \ldots \ldots \ldots$ & 18.7 \\
\hline$\$ 30,000-\$ 50,000 \ldots \ldots \ldots \ldots \ldots$ & 19.4 \\
\hline$\$ 50,000-\$ 75,000 \ldots \ldots \ldots \ldots \ldots$ & 20.7 \\
\hline$\$ 75,000-\$ 100,000 \ldots \ldots \ldots \ldots \ldots$ & 15.3 \\
\hline$\$ 100,000$ or above $\ldots \ldots \ldots \ldots \ldots$ & 25.9 \\
\hline \multicolumn{2}{|l|}{ Education $(\%)$ : } \\
\hline Less than high school . . . . . . . . . & 6.3 \\
\hline High school degree $\ldots \ldots \ldots \ldots \ldots$ & 16.3 \\
\hline Some college or associate degree $\ldots$. & 32.6 \\
\hline Bachelor's degree or more . . . . . . . . & 44.8 \\
\hline Conservatism . . . . . . . . . . & $\begin{array}{c}4.15 \\
(1.56)\end{array}$ \\
\hline
\end{tabular}

Note. $-N=2,210$. SDs are in parentheses.

school, a high school degree, some college or an associate's degree, or a college or postgraduate degree. Similarly, we created five binary variables corresponding to different levels of annual household income: less than $\$ 30,000, \$ 30,000-\$ 50,000, \$ 50,000-\$ 75,000, \$ 75,000-\$ 100,000$, and greater than $\$ 100,000$. Finally, because political conservatism could influence the relationships we test, we controlled for respondents' political ideology based on where they placed themselves on a 7-point scale ranging from "very liberal" to "very conservative."

Basic descriptive statistics and question wording for our key variables are given in table $4 .{ }^{5}$ Our central independent variable was Threat to Gender Status, which was based on respondents' beliefs that societal changes disadvantaged their gender. Men were asked this question about the status of men, and women about the status of women.

Our first dependent variable was support for the Iraq War, which was based on a single item measure of whether or not the Iraq War was "worth

\footnotetext{
${ }^{5}$ Wording of survey items overlaps substantially with those used in studies 1 and 2 because we worked with American Environics in constructing several of the questions in the AVS survey.
} 


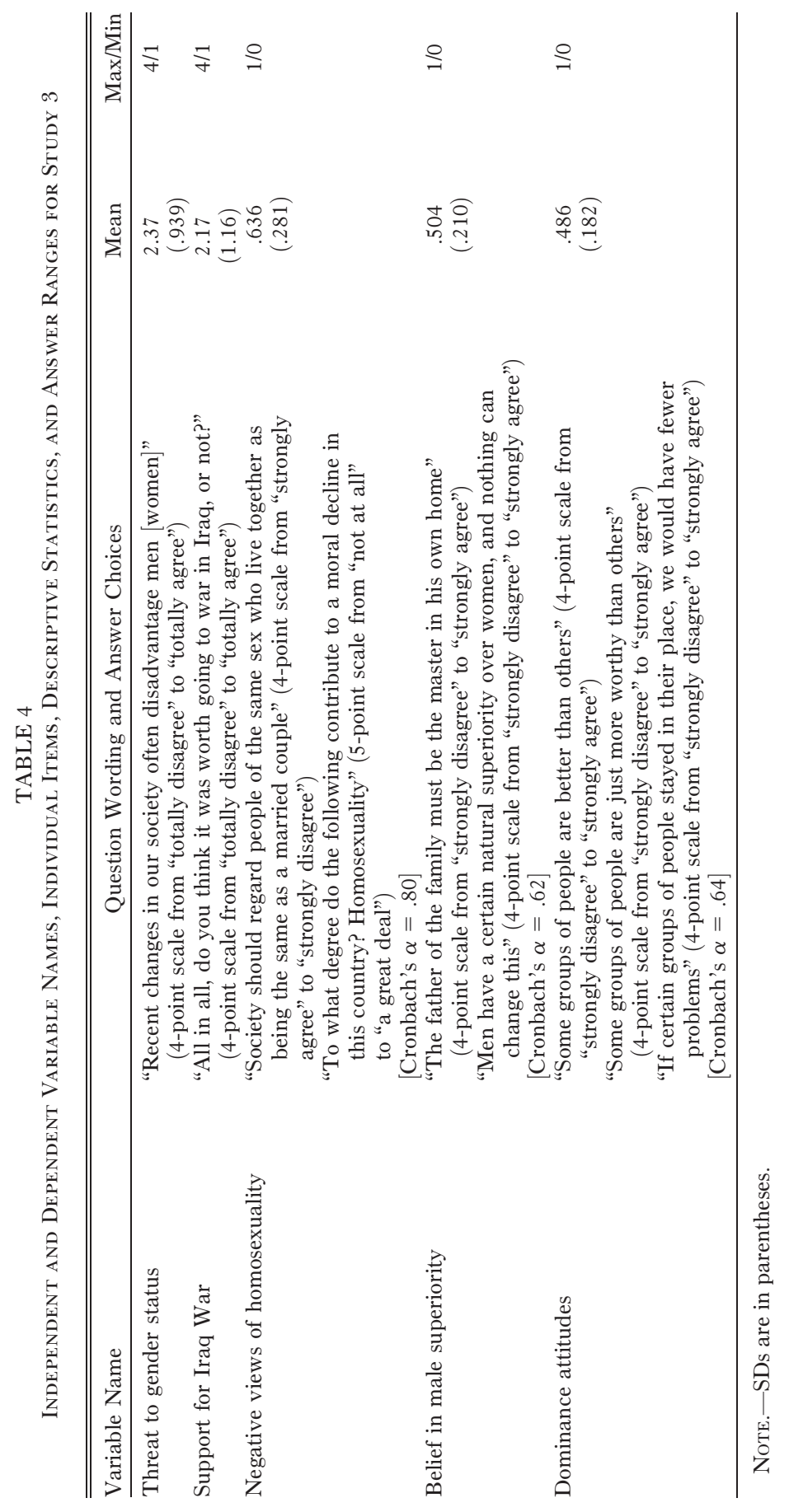


it." Our measure of negative views of homosexuality was based on a composite of items assessing views of gay marriage and whether the respondent felt that homosexuality contributes to "a moral decline in this country." Our measure of belief in male superiority was also based on a composite, this time of items assessing the degree of respondents' beliefs that men are inherently superior to women and that fathers should be masters of their home. Finally, we measured respondents' Dominance Attitudes with a composite that included three items from the same measure of social dominance orientation used in study 2 .

\section{Results}

We conducted a series of multivariate analyses of the effect of threat to gender status on each dependent variable. We predicted that threat to gender status would be associated with more extreme masculine attitudes among men, but not women. Table 5 gives results of analyses for men. Model 1 was an ordered logit model while models 2, 3, and 4 were ordinary least squares (OLS) regression models. Among the control variables, only political conservatism had consistent effects on the dependent variables, being significantly related to the dependent variable in all models presented here. In addition, college-educated respondents tended to show less endorsement of the attitudes we studied.

Looking at our predicted effects, across all four models the effect of gender status threat was significant and in the expected direction for men $(P$ 's $<05)$. These effects indicate that the more men felt that the status of their gender was threatened by social changes the more they tended to support the Iraq War, hold negative views of homosexuality, believe in male superiority, and hold strong dominance attitudes. Table 6 gives results of these same analyses for women. Here, as predicted, we see that women's reported feelings of threat were uncorrelated with these dependent variables. These findings show that there was no relationship between women's feelings that the status of their gender was under threat and the attitudes we studied $(P$ 's $>.55){ }^{6}$

We also conducted a variety of analyses investigating whether the relationship between gender status threat and men's attitudes might vary significantly by race, age, income, or education. Analyses showed no consistent interaction effects of threat with these demographic variables. Nonetheless, it is likely that these and other factors can influence the magnitude and character of masculine overcompensation, a potentially fruitful area for future research.

\footnotetext{
${ }^{6}$ All multivariate analyses were conducted on the maximum possible respondents, i.e., those respondents who gave responses to all items included in the model. Alternate analyses restricting analysis to only respondents who completed all items across all models offered nearly identical results.
} 
TABLE 5

Ordered Logit (Model 1) and Ordinary Least Squares Regression (Models 2, 3, and 4) Coefficients for Models Predicting Men's Support for Irad War, Negative Views of Homosexuality, Belief in Male Superiority, and Dominance Attitudes in Study 3

\begin{tabular}{|c|c|c|c|c|}
\hline Independent Variable & $\begin{array}{l}\text { Support } \\
\text { Iraq War } \\
\quad(1)\end{array}$ & $\begin{array}{l}\text { Negative Views } \\
\text { of Homosexuality } \\
(2)\end{array}$ & $\begin{array}{c}\text { Male } \\
\text { Superiority } \\
\text { (3) }\end{array}$ & $\begin{array}{c}\text { Dominance } \\
\text { Attitudes } \\
\text { (4) }\end{array}$ \\
\hline Age $\ldots \ldots \ldots \ldots \ldots$ & $\begin{array}{c}-.007 \\
(.004)\end{array}$ & $\begin{array}{l}.001 * * * \\
(.000)\end{array}$ & $\begin{array}{l}-.001 * * \\
(.000)\end{array}$ & $\begin{array}{l}.001 * * \\
(.000)\end{array}$ \\
\hline \multicolumn{5}{|l|}{ Race/ethncity: } \\
\hline Black . . . . . . . . & $\begin{array}{r}-.706 * \\
(314)\end{array}$ & $\begin{array}{l}.088 * * \\
(031)\end{array}$ & $.111 * * *$ & $\begin{array}{l}.025 \\
(024)\end{array}$ \\
\hline Latino/Hispanic. . . . . . . & $\begin{array}{l}.055 \\
(.215)\end{array}$ & $\begin{array}{l}.043^{*} \\
(.022)\end{array}$ & $\begin{array}{l}.062 * * \\
(.019)\end{array}$ & $\begin{array}{l}.029 \\
(.018)\end{array}$ \\
\hline Asian . . . . . . . . & $\begin{array}{c}-.402 \\
(.365)\end{array}$ & $\begin{array}{l}.067 \\
(.037)\end{array}$ & $\begin{array}{l}.069^{*} \\
(.032)\end{array}$ & $\begin{array}{l}.099 * * \\
.029)\end{array}$ \\
\hline Other. & $\begin{array}{c}-.481 \\
(.934)\end{array}$ & $\begin{array}{l}-.086 \\
(.096)\end{array}$ & $\begin{array}{c}-.122 \\
(.082)\end{array}$ & $\begin{array}{l}.007 \\
(.077)\end{array}$ \\
\hline \multicolumn{5}{|l|}{ Income: } \\
\hline$\$ 30,000-\$ 50,000$ & $\begin{array}{l}.090 \\
(.230)\end{array}$ & $\begin{array}{l}.017 \\
(.024)\end{array}$ & $\begin{array}{c}-.026 \\
(.020)\end{array}$ & $\begin{array}{l}-.017 \\
(.019)\end{array}$ \\
\hline$\$ 50,000-\$ 75,000$ & $\begin{array}{l}.240 \\
(.223)\end{array}$ & $\begin{array}{l}.014 \\
(.023)\end{array}$ & $\begin{array}{c}-.052 * * \\
(.020)\end{array}$ & $\begin{array}{c}-.049 * * \\
(.018)\end{array}$ \\
\hline$\$ 75,000-\$ 100,000$. & $\begin{array}{l}.237 \\
(.232)\end{array}$ & $\begin{array}{l}-.020 \\
(.024)\end{array}$ & $\begin{array}{c}-.029 \\
(.020)\end{array}$ & $\begin{array}{c}-.032 \\
(.019)\end{array}$ \\
\hline$\$ 100,000$ or above. . . & $\begin{array}{l}.392 \\
(.216)\end{array}$ & $\begin{array}{r}-.046^{*} \\
(.022)\end{array}$ & $\begin{array}{c}-.052 * * \\
(.019)\end{array}$ & $\begin{array}{c}-.039 * \\
(.018)\end{array}$ \\
\hline \multicolumn{5}{|l|}{ Education: } \\
\hline High school degree . . . & $\begin{array}{l}.223 \\
(.286)\end{array}$ & $\begin{array}{l}.033 \\
(.031)\end{array}$ & $\begin{array}{c}-.025 \\
(.026)\end{array}$ & $\begin{array}{c}-.068 * * \\
(.025)\end{array}$ \\
\hline Some college. . . . . . . & $\begin{array}{l}.106 \\
(.265)\end{array}$ & $\begin{array}{c}-.032 \\
(.029)\end{array}$ & $\begin{array}{c}-.038 \\
(.025)\end{array}$ & $\begin{array}{l}-.085 * * * \\
(.023)\end{array}$ \\
\hline \multicolumn{5}{|l|}{ Bachelors degree or } \\
\hline more........... & $\begin{array}{l}-190 \\
(.265)\end{array}$ & $\begin{array}{c}-.051 \\
(.029)\end{array}$ & $\begin{array}{c}-.067 * * \\
(.025)\end{array}$ & $\begin{array}{l}-.111^{* * * *} \\
(.023)\end{array}$ \\
\hline Conservatism . . . & $\begin{array}{l}.806 * * * \\
(.047)\end{array}$ & $\begin{array}{l}.091 * * * \\
(.004)\end{array}$ & $\begin{array}{l}.033 * * * \\
.004)\end{array}$ & $\begin{array}{l}.009 * * \\
(.003)\end{array}$ \\
\hline \multicolumn{5}{|l|}{ Threat to gender } \\
\hline status. & $\begin{array}{l}.226 * * * \\
(.064)\end{array}$ & $\begin{array}{l}.038 * * * \\
(.007)\end{array}$ & $\begin{array}{l}.041 * * * \\
(.006)\end{array}$ & $\begin{array}{l}.038^{* * * *} \\
(.005)\end{array}$ \\
\hline Intercept . & & $\begin{array}{l}.142^{* * *} \\
(.051)\end{array}$ & $\begin{array}{l}.420 * * * \\
(.036)\end{array}$ & $\begin{array}{l}.427 * * * * \\
(.033)\end{array}$ \\
\hline 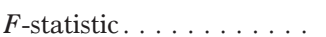 & & $40.70 * * *$ & $19.01 * * *$ & $9.58 * * *$ \\
\hline$R^{2} \ldots \ldots \ldots \ldots$ & & .387 & .188 & .106 \\
\hline$\ldots$ & 1,120 & 1,157 & 1,162 & 1,151 \\
\hline
\end{tabular}

NotE.-SEs are in parentheses. Omitted categories for race/ethnicity, income, and education are "white," "less than $\$ 30,000$," and "less than high school," respectively.

$* P<.05$.

** $P<.01$.

$* * * P<.001$. 
TABLE 6

Ordered logit (Model 1) and Ordinary Least Souares Regression (Models 2, 3 , and 4) Coefficients for Models Predicting Women's SQupport for IraQ War, Negative Views of Homosexuality, Belief in Male Superiority, and Dominance Attitudes in Study 3

\begin{tabular}{|c|c|c|c|c|}
\hline Independent Variable & $\begin{array}{l}\text { Support } \\
\text { Iraq War } \\
\quad(1)\end{array}$ & $\begin{array}{l}\text { Negative Views } \\
\text { of Homosexuality } \\
(2)\end{array}$ & $\begin{array}{c}\text { Male } \\
\text { Superiority } \\
(3)\end{array}$ & $\begin{array}{c}\text { Dominance } \\
\text { Attitudes } \\
(4)\end{array}$ \\
\hline Age $\ldots \ldots \ldots \ldots \ldots$ & $\begin{array}{c}-.011^{* *} \\
(.004)\end{array}$ & $\begin{array}{l}.001^{*} \\
(.000)\end{array}$ & $\begin{array}{l}.001 \\
(.000)\end{array}$ & $\begin{array}{l}.001 * \\
(.000)\end{array}$ \\
\hline \multicolumn{5}{|l|}{ Race/ethncity: } \\
\hline Black . . . . . . . . . & $\begin{array}{c}-.859 * * \\
(.260)\end{array}$ & $\begin{array}{l}.082 * * \\
(.027)\end{array}$ & $\begin{array}{l}.121 * * * \\
(.022)\end{array}$ & $\begin{array}{c}-.022 \\
(.019)\end{array}$ \\
\hline Latino/Hispanic . . . . . & $\begin{array}{c}-.179 \\
(.207)\end{array}$ & $\begin{array}{l}.007 \\
(.023)\end{array}$ & $\begin{array}{l}.057 * * \\
(.020)\end{array}$ & $\begin{array}{l}.025 \\
(.017)\end{array}$ \\
\hline Asian . . & $\begin{array}{r}-.435 \\
(.381)\end{array}$ & $\begin{array}{l}.017 \\
(.047)\end{array}$ & $\begin{array}{l}.127 * * \\
(.039)\end{array}$ & $\begin{array}{l}.059 \\
(.034)\end{array}$ \\
\hline Other . & $\begin{array}{c}.579 \\
(.708)\end{array}$ & $\begin{array}{l}.080 \\
(.102)\end{array}$ & $\begin{array}{c}-.064 \\
(.079)\end{array}$ & $\begin{array}{l}.084 \\
(.068)\end{array}$ \\
\hline \multicolumn{5}{|l|}{ Income: } \\
\hline$\$ 30,000-\$ 50,000 \ldots \ldots$ & $\begin{array}{c}-.073 \\
(.189)\end{array}$ & $\begin{array}{c}-.017 \\
(.021)\end{array}$ & $\begin{array}{c}-.012 \\
(.018)\end{array}$ & $\begin{array}{c}-.044 * * \\
(.015)\end{array}$ \\
\hline$\$ 50,000-\$ 75,000 \ldots \ldots$ & $\begin{array}{c}.218 \\
(.188)\end{array}$ & $\begin{array}{l}.006 \\
(.022)\end{array}$ & $\begin{array}{c}-.008 \\
(.018)\end{array}$ & $\begin{array}{c}-.040 * \\
(.016)\end{array}$ \\
\hline$\$ 75,000-\$ 100,000 \ldots$ & $\begin{array}{c}-.035 \\
(.226)\end{array}$ & $\begin{array}{c}-.022 \\
(.026)\end{array}$ & $\begin{array}{l}.002 \\
(.022)\end{array}$ & $\begin{array}{c}-.045^{*} \\
(.019)\end{array}$ \\
\hline$\$ 100,000$ or above $\ldots$ & $\begin{array}{l}.123 \\
(.199)\end{array}$ & $\begin{array}{c}-.016 \\
(.024)\end{array}$ & $\begin{array}{r}-.010 \\
(.020)\end{array}$ & $\begin{array}{c}-.044^{*} \\
(.017)\end{array}$ \\
\hline \multicolumn{5}{|l|}{ Education: } \\
\hline High school degree . . . & $\begin{array}{l}.496 \\
(.297)\end{array}$ & $\begin{array}{l}.081 * \\
(.033)\end{array}$ & $\begin{array}{l}.016 \\
(.028)\end{array}$ & $\begin{array}{c}-.016 \\
(.024)\end{array}$ \\
\hline Some college. . . . . . & $\begin{array}{l}.234 \\
(.278)\end{array}$ & $\begin{array}{l}.050 \\
(.031)\end{array}$ & $\begin{array}{l}.001 \\
(.026)\end{array}$ & $\begin{array}{c}-.062 * * \\
(.022)\end{array}$ \\
\hline $\begin{array}{l}\text { Bachelors degree or } \\
\text { more } \ldots \ldots \ldots\end{array}$ & $\begin{array}{c}-.119 \\
(.286)\end{array}$ & $\begin{array}{l}.007 \\
(.032)\end{array}$ & $\begin{array}{c}-.072 * * \\
(.027)\end{array}$ & $\begin{array}{c}-.079 * \\
(.023)\end{array}$ \\
\hline Conservatism ... . & $\begin{array}{l}.630^{* * * *} \\
(.048)\end{array}$ & $\begin{array}{l}.103 * * * \\
(.005)\end{array}$ & $\begin{array}{l}.045 * * * \\
(.004)\end{array}$ & $\begin{array}{l}.011 * * \\
(.004)\end{array}$ \\
\hline Threat to gender & & & & \\
\hline status $\ldots \ldots \ldots$ & $\begin{array}{c}-.062 \\
(.071)\end{array}$ & $\begin{array}{l}.012 \\
(.008)\end{array}$ & $\begin{array}{l}.011 \\
(.007)\end{array}$ & $\begin{array}{l}.007 \\
(.006)\end{array}$ \\
\hline Intercept $\ldots$. & & $\begin{array}{l}.058 \\
(.047)\end{array}$ & $\begin{array}{l}.244^{* * * *} \\
(.039)\end{array}$ & $\begin{array}{l}.436 * * * \\
(.034)\end{array}$ \\
\hline$F$-statistic. . . & & $38.11 * * *$ & $16.25 * * *$ & $5.84 * * *$ \\
\hline$R^{2} \ldots \ldots \ldots \ldots$ & & .346 & .184 & .075 \\
\hline$N \ldots \ldots \ldots \ldots$ & 982 & 1,026 & 1,027 & 1,025 \\
\hline
\end{tabular}

Note.-SEs are in parentheses. Omitted categories for race/ethnicity, income, and education are "white," "less than $\$ 30,000$," and "less than high school," respectively.

$$
\begin{aligned}
& * P<.05 . \\
& * * P<.01 . \\
& \text { *** } P<.001 .
\end{aligned}
$$


American Journal of Sociology

\section{Discussion}

Study 3 offers further support for the masculine overcompensation thesis, this time in a more diverse sample than those used in studies 1 and 2. Men who reported that social changes threatened the status of men reported greater support for war, more negative views of homosexuality, stronger belief in male superiority, and stronger dominance attitudes. Women, on the other hand, showed no such relationships.

Perhaps the most significant concern with the study involves inference of causation from the correlations we found. These correlations could, for example, be driven by a reverse causal process: a tendency for individuals adopting more traditional masculine attitudes to more readily perceive that the status of masculinity is under threat, perhaps because they endorse a narrower conception of masculinity. Alternatively, some third variable that we failed to control for in our models could drive the observed associations. For example, though we controlled for political conservatism, it could be that individuals with a more traditional cultural worldview are be more inclined to see cultural change as threatening and to adopt traditionally masculine attitudes. We believe these are credible concerns and that the relationships we found could be driven in part by these processes. The results of the controlled experiments of studies 1 and 2, however, offer strong evidence for a causal effect of perceived masculinity threat on men's masculine attitudes. This experimental evidence helps to address the limited capacity for correlational research to support causal conclusions, providing credibility to our causal claims.

Another concern with this study is that the nonrepresentativeness of the sample and the very low response rate might threaten the validity of the data. These aspects of the data set pose serious concerns for matching the magnitude of the coefficients and intercepts from our regression models with the "true" effects that exist in the population. However, our purpose here was to test whether the relationship between threat and masculine attitudes would be significant and positive for men (but not women) in a more diverse sample than those used in studies 1 and 2. The biggest threat posed by the nonrepresentativeness and the low response rate of the survey we used is the possibility that selection into our sample might somehow be correlated with our predicted effects. Alhough this is possible, we see little reason why a group that is overrepresented in our sample would be uniquely sensitive to masculinity (but not femininity) threats, thus driving the associations (and nonassociations) we observe. Further, many of the effects for control variables given in tables 5 and 6 are consistent with past research, that is, the link between conservatism and support for war (Zaller 1991) — suggesting that the data set's validity is not fundamentally compromised by the response rate. 
One possible alternative explanation for our findings in study 3 is that the rising status of women in educational and professional domains may have led women to report low levels of perceived status threat, impairing our ability to detect any possible effects on gendered attitudes. However, while men did report significantly higher levels of threat $(M=2.41)$ than women $(M=2.32 ; t=2.36 ; P=.02)$, the magnitude of the difference was likely too small to support this alternative explanation.

These results extend the findings of our prior studies in several ways. First, they offer external validity for the findings of studies 1 and 2, demonstrating a relationship between men's feelings of masculinity threat and more extreme masculine attitudes in a diverse sample of Americans studied outside of a laboratory setting. They further suggest that perception that social changes have diminished the status of men may affect men in ways similar to the individual-level gender identity threats of studies 1 and 2 .

\section{STUDY 4: TESTOSTERONE AND OVERCOMPENSATION}

The results of studies 1-3 show a close tie between threats to men's masculinity and men's enactment of more extreme masculine attitudes, especially dominance-related attitudes. As noted above, past research has linked men's testosterone levels with sensitivity to status threats and dominance behaviors, suggesting the possibility that testosterone might be implicated in the masculine overcompensation process.

Here we explore two rival hypotheses suggested by past work regarding the role of testosterone in masculine overcompensation. First, it is possible that testosterone levels mediate the relationship between threats and extreme masculine attitudes, with threats leading to increased testosterone levels and, thereafter, masculine attitudes. Alternatively, basal testosterone levels could moderate the strength of the effect of threats on masculine attitudes, with men higher in basal testosterone being more prone to overcompensation.

To test these possibilities, we returned to a laboratory context. Our study was largely identical to study 1 except that it was conducted only among men and at several points participants were asked to provide saliva samples. These samples were subsequently used to measure testosterone levels, allowing us to test whether testosterone mediates or moderates the masculine overcompensation effect.

\section{Method}

Design and participants. - The study features a 2 (participants' gender identity was threatened/not) condition experimental design. Fifty-four undergraduate men at the University of Iowa participated in the study for pay. 
Procedure.- Study procedures were largely identical to those of studies 1 and 2. Participants were escorted to testing rooms where they took part in the study individually. As in studies 1 and 2, they first completed a demographic questionnaire and gender identity survey (Bem 1974). They were then given randomly determined feedback on the results of their gender identity survey before being asked to complete a Political and Religious Views Survey and a poststudy questionnaire.

At regular intervals throughout the study research assistants asked each participant to provide a saliva sample in a sterile cryogenic vial. Saliva collection was consistent with standard procedures used in past research (e.g., Schultheiss, Campbell, and McClelland 2005). Sugarless chewing gum was made available to stimulate participants' saliva production if necessary (Dabbs 1991). In all, four samples were collected. The first was collected upon completion of the consent form. The second sample was collected upon receiving the gender identity feedback, though well before any changes in testosterone levels could be detected in a saliva sample. The third sample was collected following completion of the Political and Religious Views Survey. The research assistant delayed returning to the participant's testing room to assure that the third saliva sample was collected at least 15 minutes after the gender identity feedback was administered, allowing changes in participants' testosterone levels to be detectable in saliva (Schultheiss et al. 1999; Schultheiss and Rohde 2002). The fourth sample was collected after completion of the final survey packet. Finally, participants were sensitively debriefed and paid.

Dependent measures. - We measured participants' support for the Iraq War and negative views of homosexuality using the same composites as in study 1 (Cronbach's $\alpha$ 's $=.88, .92$, respectively). As a third dependent measure we also added two questions assessing support for President George W. Bush. Support for President Bush could be perceived as a masculine-typed attitude given popular perceptions of both his personality and political positions (e.g., Ducat 2004; Christensen and Ferree 2008; Messerschmidt 2010). Specifically, President Bush's support for preemptive war, a more permissive torture policy, capital punishment, his opposition to gun control, and other similar positions may have led Americans to associate him with masculine traits, including dominance and aggression. To create a composite measure of Supportfor President Bush, we asked participants to indicate on 7-point scales "How much do you approve of the job President Bush is doing in general?" and "How successful do you think President Bush has been at his job?" (Cronbach's $\alpha=.95)$.

Testosterone.-Saliva samples were refrigerated at $-20^{\circ} \mathrm{C}$ before being shipped to Salimetrics (State College, Penn.) for assaying and analysis of testosterone levels. All samples were assayed for salivary testosterone using a highly sensitive enzyme immunoassay. Each saliva sample was measured in 
duplicate to improve reliability. The test had a lower limit of sensitivity of $1.0 \mathrm{pg} / \mathrm{ml}$, an average intra-assay coefficient of variation of $4.6 \%$, and an average inter-assay coefficient of variation of $9.8 \%$. For more details of the enzyme immunoassay procedure, see Salimetrics (2010).

We classified testosterone levels in the first two saliva samples as premanipulation and levels in the latter two samples as postmanipulation. Levels from the two assays of each of the first two samples were averaged to form a composite measure of premanipulation basal testosterone levels (Cronbach's $\alpha=.95$ ), and the two assays of the latter two samples were averaged to create a postmanipulation testosterone composite (Cronbach's $\alpha=.96)$.

\section{Results}

Mediation. - The mediation hypothesis predicts that men whose masculinity is threatened will exhibit increased testosterone, and this higher testosterone will in turn lead to more masculine attitudes. As a first step in evaluating the mediation claim, we tested to see if the masculinity threat had a significant effect on testosterone levels. We found no significant difference between the postmanipulation testosterone levels of threatened participants ( $M$ $=109.54 \mathrm{pg} / \mathrm{ml})$ and those of unthreatened participants $(M=119.28 \mathrm{pg} / \mathrm{ml}$; $t(54)=1.35, P>.15) .{ }^{7}$ We also tested the effect of masculinity threat on postmanipulation testosterone levels while controlling for premanipulation testosterone levels in a multiple regression analysis. Again, we found no significant effect of threat on subsequent testosterone levels $(P>.65)$.

Moderation.-Finding no evidence for mediation, we turn next to the possibility that basal testosterone levels might moderate the masculine overcompensation effect. To test for moderation, we first centered our measure of participant's basal testosterone (Aiken and West 1991). To test whether participants' of different testosterone levels responded differently to masculinity threats, we conducted a series of multiple regression analyses entering basal testosterone level, masculinity threat, and the interaction of the two as predictors of support for the Iraq War, negative views of homosexuality, and support for President Bush. ${ }^{8}$ Table 7 gives results of these analyses.

\footnotetext{
${ }^{7}$ Because changes in levels of testosterone might not be detectable for longer than we anticipated, or might attenuate, we also tested for effects of the masculinity threat in the third and fourth samples individually and found none ( $P$ 's $=.20, .21$, respectively).

${ }^{8}$ Past research on the moderating role of testosterone has treated it as either a continuous (Mehta et al. 2008) or dichotomous (e.g., Newman et al. 2005; Josephs et al. 2006) variable. Accordingly, we explored alternate versions of the regression models given here in which testosterone was either trichotomized or dichotomized in various ways (e.g., median split, highest third of distribution vs. lowest two-thirds). Bayesian information criterion (BIC) statistics for these models indicated that the continuous analyses reported here fit the data as well as, or better than, any of these alternatives.
} 
American Journal of Sociology

TABLE 7

Ordinary Least SQuares Regression Coefficients for Models Predicting Support for Irae War, Negative Views of Homosexuality, and Support for President Bush in STUdy 4

\begin{tabular}{|c|c|c|c|}
\hline Independent Variable & $\begin{array}{c}\text { Support Iraq War } \\
(1)\end{array}$ & $\begin{array}{l}\text { Homophobia } \\
\text { (2) }\end{array}$ & $\begin{array}{c}\text { Support for } \\
\text { President Bush } \\
\text { (3) }\end{array}$ \\
\hline Basal testosterone. . . . . . . . & $\begin{array}{c}-.006 \\
(.007)\end{array}$ & $\begin{array}{c}-.004 \\
(.010)\end{array}$ & $\begin{array}{l}.005 \\
(.007)\end{array}$ \\
\hline Masculinity threat. . . . . . & $\begin{array}{l}.633^{+} \\
(.357)\end{array}$ & $\begin{array}{l}.581 \\
(.558)\end{array}$ & $\begin{array}{l}1.07 * * \\
(.375)\end{array}$ \\
\hline Threat $\times$ testosterone $\ldots \ldots$ & $\begin{array}{l}.028^{* *} \\
(.010)\end{array}$ & $\begin{array}{l}.028^{+} \\
(.016)\end{array}$ & $\begin{array}{l}.027 * \\
(.011)\end{array}$ \\
\hline Intercept $\ldots \ldots \ldots \ldots \ldots$ & $\begin{array}{l}2.56 * * * \\
(.247)\end{array}$ & $\begin{array}{l}2.98 * * * \\
(.386)\end{array}$ & $\begin{array}{l}2.51 * * * \\
(.260)\end{array}$ \\
\hline$F$-statistic . . . . . . . . & $3.83^{*}$ & 1.60 & $4.86 * *$ \\
\hline$R^{2} \ldots \ldots \ldots \ldots$ & .187 & .087 & .226 \\
\hline $\begin{array}{l}\text { Note. }-N=54 . \\
+P<.10 . \\
* P<.05 \\
* * P<.01 \\
* * * P<001\end{array}$ & & & \\
\hline
\end{tabular}

Looking first at participants' support for the Iraq War, we found a nonsignificant main effect of basal testosterone level. We also found a marginally significant, positive effect of masculinity threat, indicating that at the mean level of basal testosterone, threatened men reported greater support for the Iraq War. Most relevant to the moderation hypothesis, the interaction of masculinity threat and testosterone level is positive and significant. These relationships are depicted in figure 2, which shows that responses to masculinity threats were more pronounced among higher-testosterone men. While higher-testosterone men responded to masculinity threats with greater support for the Iraq War, lower-testosterone men whose masculinity was threatened actually tended to report lower levels of support for the war.

Turning to participants' views of homosexuality, here we find nonsignificant effects of both basal testosterone level and masculinity threat. The interaction of these terms, however, was again positive and significant. Figure 3 illustrates this interaction effect showing that the effect of masculinity threats on men's views of homosexuality varied greatly depending on premanipulation testosterone levels. The higher were men's testosterone levels, the more they responded to masculinity threats with negative views of homosexuality. Low-testosterone men, however, showed the opposite pattern, with threat leading to less negative views of homosexuality. 


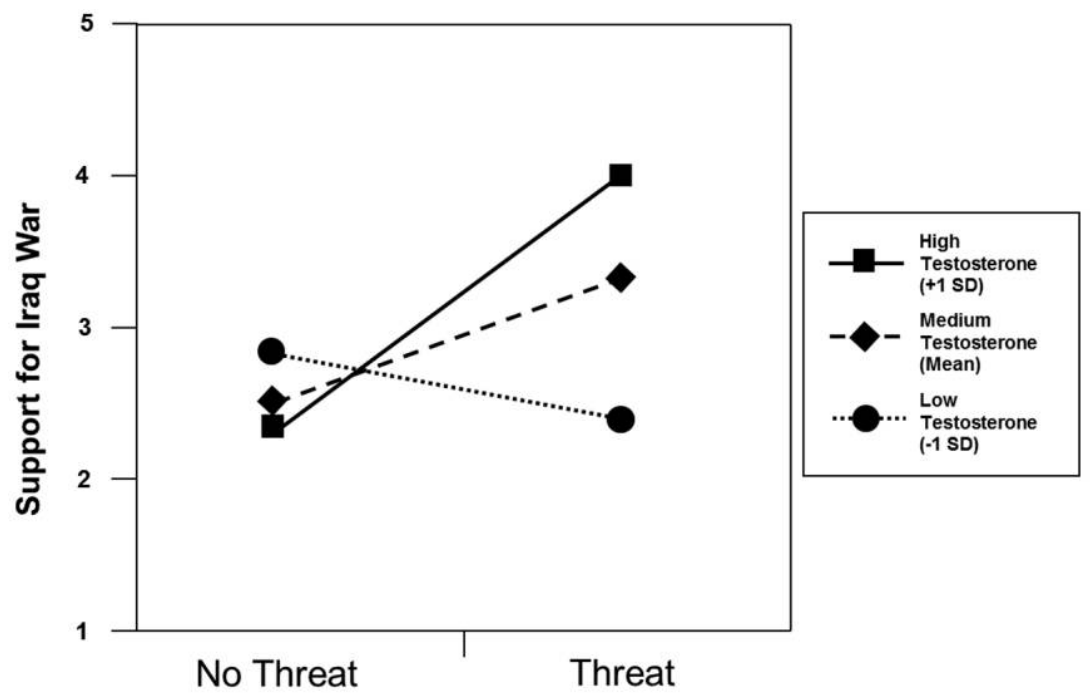

FIG. 2.-Effects of testosterone and masculinity threat on support for the Iraq War

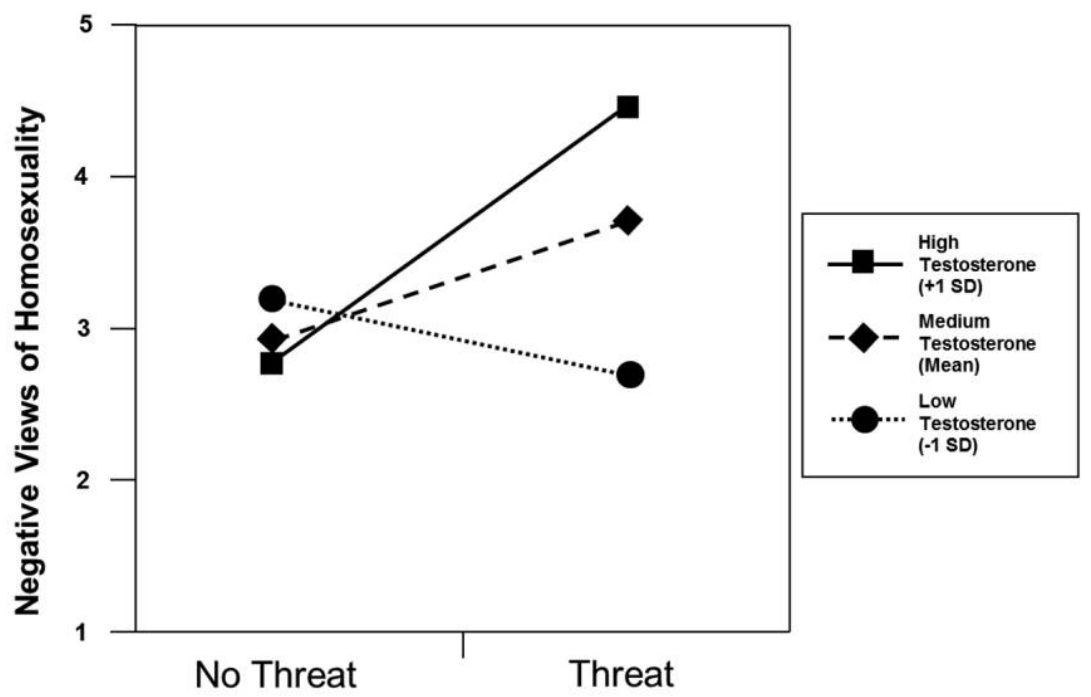

F IG. 3.-Effects of testosterone and masculinity threat on negative views of homosexuality. 
American Journal of Sociology

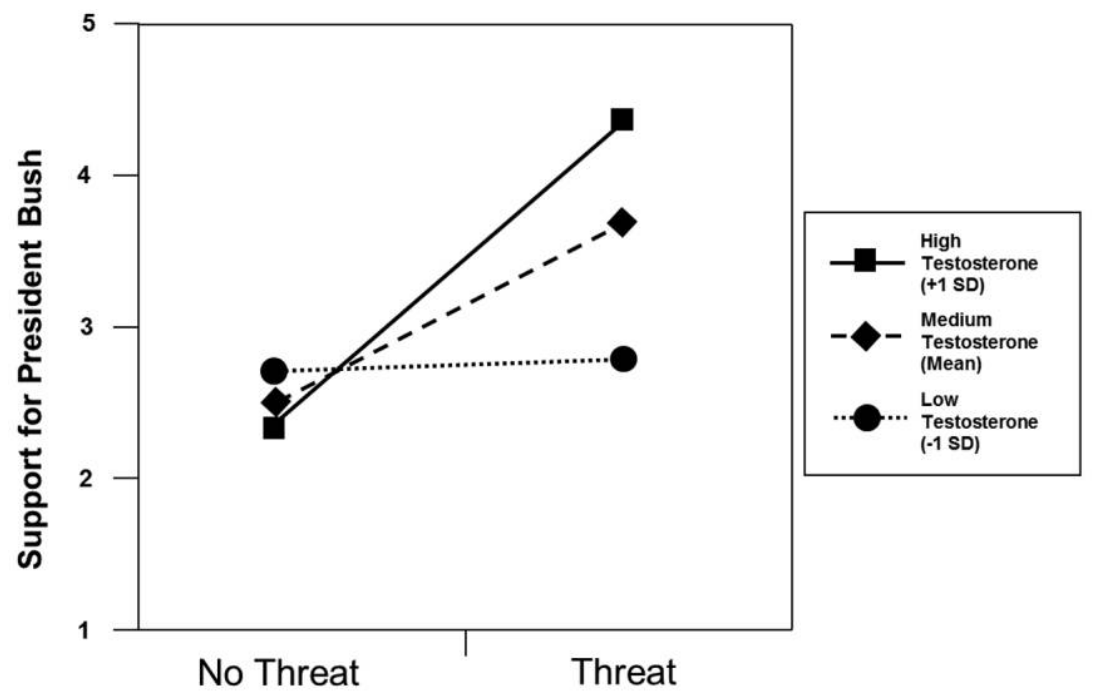

FIG. 4.-Effects of testosterone and masculinity threat on support for President Bush

Finally, analyzing participants' support for Bush, we found a nonsignificant effect of basal testosterone level and a positive, significant effect of masculinity threat. The latter effect indicates that, at the mean level of testosterone level, masculinity threats led participants to report greater support for Bush. The moderation hypothesis was again supported, as the interaction of testosterone and threat was significant and positive. As shown in figure 4, at higher levels of basal testosterone, participants were more likely to react to masculinity threats with support for Bush. Higher-testosterone men reported greater support for Bush than their unthreatened counterparts, but lower testosterone men showed no change in support for Bush as a result of threats.

\section{Discussion}

While we found no evidence that testosterone mediated the masculine overcompensation effect, in study 4 we found consistent support for a moderation effect. The interaction of basal testosterone and masculinity threat was significant for all three dependent measures we investigated: support for the Iraq War, negative views of homosexuality, and support for President Bush. In all cases higher-testosterone men were more likely to react to masculinity threats by adopting more masculine attitudes.

We found that the effects of testosterone were highly contingent. For example, among men whose masculinity was not threatened, we found no main effects of testosterone as higher- and lower-testosterone men indicated 
roughly equivalent support for the Iraq War, negative views of homosexuality, and support for President Bush. By contrast, the significant effects we found for the interaction of masculinity threats and basal testosterone levels indicate that, when masculinity was threatened, basal testosterone levels were positively associated with masculine attitudes. These results fit well with a growing body of research showing that levels of testosterone do not typically have significant main effects but that in combination with social stimuli like masculinity or status threats, they can have quite strong interaction effects (e.g., Kemper 1990; Josephs et al. 2006). In a sense, the effects of testosterone levels must be "activated" by situational factors if they are to affect behavior or attitudes. Taken together with past research, our findings suggest that higher-testosterone men are more attentive and responsive to threats to their status, reacting to them with dominance-related behaviors and attitudes. More generally, these findings are promising for future research on the interaction of hormones and social context. ${ }^{9}$

\section{GENERAL DISCUSSION}

Results of four studies offer consistent support for the masculine overcompensation thesis. In study 1 , men whose masculinity was threatened expressed more masculine attitudes than men whose masculinity was not. Women, however, were apparently unaffected by equivalent feedback. Results of study 2 showed that men whose masculinity was threatened adopted stronger dominance attitudes, suggesting that these threats motivate men to reassert their support for such hierarchies and their position in them. Study 3 replicated these findings in the context of a large-scale survey study, showing that results were robust in a more diverse sample. Results of study 3 further suggested that perceptions that cultural changes threaten men's standing may serve as masculinity threats in a way similar to the individual-level threats of studies 1 and 2 .

Finally, because past research has linked masculinity and dominance with testosterone levels, study 4 investigated what role testosterone might play in masculine overcompensation. While we found no evidence that testosterone levels mediated the effect, we did find evidence for moderation. Men who were higher in basal testosterone were more responsive to masculinity threats, expressing more masculine attitudes following these threats. Low-testosterone men, on the other hand, did not overcompensate.

Taken together these findings help establish the validity of masculine overcompensation. Multiple studies using both laboratory experimental

${ }^{9}$ These results are the first showing a causal effect of hormone levels on political attitudes. Note that one past study showed an effect of election outcomes on partisans' testosterone levels (Stanton et al. 2009). 
and correlational field methods supported the claim. These findings offer more convincing support together as experiments are uniquely able to answer the weaknesses of correlational field research, establishing causality by controlling for possible confounding variables, thus reducing concerns that observed correlations could be spurious. Conversely, large-scale, correlational field research addresses weaknesses of laboratory experiments by testing hypothesized relationships outside the potentially artificial laboratory context and investigating whether results are robust in more diverse populations than the convenience samples typical of laboratory studies. In addition, the present research also looked at masculine overcompensation at three different levels of analysis, showing how this interactional process may be implicated in macrolevel patterns of political and cultural attitudes, while itself being shaped by endocrinological factors.

More generally, the present research is consistent with theoretical work on both masculinity and identity. In accordance with identity theories, we found that men did not simply strive to compensate when their masculinity was threatened. Rather, they overcompensated, as if striving to pull their average level of masculinity up to more acceptable levels.

Masculinity theorists have typically argued that masculinity is both narrowly defined and more socially valued than femininity, at least in contemporary American culture. Our results are also consistent with these arguments, as men but not women showed consistent responsiveness to threats in our studies. Men not only responded by adjusting their attitudes to be more masculine upon receiving feedback that they lacked masculinity, they also reported greater negative affect (study 1), suggesting greater sensitivity to threat. We found no corresponding tendency for gender identity threats to foster negative emotions in women.

Our application of masculinity theory here also suggests that the extent to which men will overcompensate in the face of masculinity threats is likely to vary across cultures. We expect masculine overcompensation to be most likely and most pronounced in cultural contexts that (1) conceptualize acceptable masculinity in a very narrow way and (2) value masculinity at a relatively high level. Where these factors are both low, where masculinity is more broadly defined and valued similarly to femininity, it should be harder to threaten men's masculinity and they should be less motivated to reclaim it. Future cross-cultural research should explore whether these macrocultural factors do in fact moderate the performance of masculinity in everyday life in the way we theorize. In addition, future research could explore causal links between the definition and valuation of gender identities across social contexts. For example, it may be that the high valuation of masculinity tends to lead to it being narrowly defined as people struggle to understand why someone would violate the standards of a highly valued identity. 
Theorists further argue that striving for masculinity in the face of threats is a near ubiquitous aspect of men's lives because of the hierarchical nature of masculinity, the esteem accorded to it, and the presence of a narrowly defined set of ideal masculine traits. Our results are consistent with the prominent role of threat in the maintenance of masculinity. We found evidence linking masculinity threats to diverse outcomes, including domestic and foreign policy views, cultural attitudes, consumption practices, and more general views of hierarchy and inequality between groups. We also found that both situationally induced threats (studies 1,2, and 4) and perceptions of the declining status of men in the larger society (study 3 ) were related to the expression of relatively extreme masculine attitudes.

We found evidence that the core aspect of masculinity that men enacted in the face of threats was dominance, a fundamental basis of hierarchy and status differentiation among men and boys (e.g., Johnson 2005; Martin 2009). Experimental and field data showed that threatened men expressed both greater desire for standing within, and support for the existence of, dominance hierarchies. Further, the effects we found for belief in the superiority of men, derogation of homosexuals, support for war, and desire for a large, powerful vehicle may also reflect such dominance striving. These results fit well with past arguments that masculinity is arrayed hierarchically, with men competing to pursue greater masculine status according to reigning cultural definitions of what are valued masculine traits. On such a playing field men must respond to threats and provocations with demonstrations of aggression, power, and dominance if they hope to achieve masculine status relative to other men.

\section{Limitations and Future Directions}

Still, the present research leaves open important questions that present fruitful opportunities for future research. A critical point in our argument is that women will typically react less to femininity threats than men do to masculinity threats. But there are other, alternative explanations for the gender asymmetry we observed in our studies. For example, it could be that women are equally responsive to gender identity threats but that our focus on masculine attitudes did not allow us to detect women's efforts to restore a feminine gender identity. While plausible, this interpretation cannot account for the fact that threats led men but not women in study 1 to report greater negative affect, consistent with our reasoning that gender identity threats affect men more than women.

But this is not to say that feminine overcompensation is impossible. On the contrary, past theory and research argue that a hegemonic feminine ideal exists for women (e.g., Ussher 1997; Krane et al. 2004) and find that, accord- 
ingly, women sometimes overcompensate in the face of threats to their femininity (e.g., Griffin 1998). We argue here that, in the American context, feminine overcompensation will typically require larger threats than those studied here and will be more likely in cultural contexts where femininity is defined in narrow, traditional ways.

Further, our application of masculinity theory suggests that the more narrowly defined and highly socially valued femininity is in a given cultural context, the more likely feminine overcompensation will be. Future crosscultural research could explore if feminine overcompensation is more common in cultures that construct acceptable femininity in very specific terms and value it more highly, relative to cultures lower on these two criteria.

Another very fundamental issue that this research leaves unresolved is whether masculine overcompensation is driven more by identity or reputational concerns. When men respond to threats with masculinity striving, are they seeking to restore a fundamental aspect of their self-concept that they deeply value or to restore reputational standing in the eyes of others? The relatively high social esteem associated with masculinity could affect either process, increasing the reputational rewards for men who behave in a masculine way and also increasing men's private valuation of a masculine gender identity. The dependent measures used in the present research involved anonymous surveys of masculine-typed attitudes, suggesting it is unlikely that greater masculinity was motivated by a desire to impress others. But despite this we think it is most likely that masculine overcompensation is motivated by both identity and status concerns. It could be that responses on our anonymous surveys reflect heuristics developed in public settings where masculine status is at stake. This interpretation was not directly tested here, however, and should be evaluated. For example, as a way to get at the roles of identity versus status concerns, future research could experimentally manipulate whether participants' gender identity feedback was kept private or made public to several other study participants (see Lightdale and Prentice 1994).

A possible concern with the present research is that participants in studies 1, 2, and 4 might have construed the feedback they received about their masculinity as referring more to their sexual orientation than masculinity per se. This alternative interpretation of our results is suggested by past research noting that, for young American men, being masculine is deeply intertwined with maintaining a heterosexual identity (Pascoe 2005). While possible, we believe that the feedback we gave in our studies was primarily interpreted as referring to participants' masculinity and femininity. The gender identity test that participants completed (see app. A) made no reference to sexuality nor did the feedback participants received. In addition, we found convergent results in study 3, which employed a self-report measure 
of perceived gender identity threat. Nonetheless, it would be a worthwhile line of future research to explore how much masculinity feedback is subjectively construed as sexuality feedback. It could also be interesting to investigate the opposite mediating process, that the effect of sexual orientation feedback on men's subsequent behavior might be mediated by feelings of masculinity threat.

\section{The Role of Testosterone}

While we have consistently found no results of gender identity threat for women in the studies reported here, the results of study 4 might lead one to wonder if women high in basal testosterone could also be responsive to gender identity feedback, perhaps even being sensitive to the suggestion that they possess feminine traits. A variety of research suggests that links between testosterone and behavior operate in similar ways for men and women ( $\mathrm{Ma}$ zur and Booth 1998; Josephs et al. 2003; Newman et al. 2005), and some past studies have shown that basal testosterone moderates responses to statusrelevant feedback in both men and women (e.g., Mehta et al. 2008). The distributions of basal testosterone among men and women are such that basal testosterone levels at the top end of typical distributions for women are similar to the lowest levels seen among men (Salimetrics 2010), meaning that only women with extremely high basal testosterone (roughly, the top $5 \%$ of the distribution) would possess levels akin to the men in study 4 who showed responses to masculinity threats. Thus, a worthwhile avenue for future research could be to explore whether women with very high testosterone might be responsive to threatening gender identity feedback in a way analogous to men.

This reasoning also suggests an intriguing, alternate theory to the one presented here. It might be that who engages in overcompensation is a matter of basal testosterone level more than gender, with moderate $=$ and high-testosterone men (and perhaps extremely high-testosterone women) exhibiting strong responses to gender identity-threatening feedback and low-testosterone men and most women being largely unaffected. Additionally, past research indicates that those high in basal testosterone may be sensitive to feedback threatening their status in general (Josephs et al. 2006; Mehta et al. 2008), not just gender identity feedback. Taken together with the present research, this suggests the possibility that people with relatively higher basal testosterone levels react to low status feedback by enacting attitudes and behaviors intended to assert or reclaim dominance. This alternate theory fits well with contemporary testosterone research, but it diverges in important ways from the theoretical reasoning presented here and merits further empirical examination. 
American Journal of Sociology

\section{Is Overcompensation a Biological Process?}

One interpretation of the results of study 4 is that masculine overcompensation should be viewed as a biological process, but we would caution against this interpretation. First, the study fits well with other research showing that testosterone levels rarely have main effects on human behavior; more common are findings that testosterone levels interact with social stimuli to affect behavior (e.g., Newman et al. 2005; Josephs et al. 2006). Further, in our research we found main effects of situational threats on masculine behaviors across three studies where testosterone levels were not considered. But, as shown in figures 2-4, we found no differences in masculine attitudes by basal testosterone level among unthreatened men. Testosterone effects were only observed when a situational threat, in a sense, "activated" them.

But, more generally, viewing biological and social factors as necessarily separate and competing to explain zero-sum variance in human behavior reinforces a false and antiquated dichotomy. Social and biological processes are deeply intertwined. Just as we have documented here a physiological factor that influences human behavior, social factors shape biological processes in important ways. For example, life course events (Archer 2006) and situational stimuli (Schultheiss et al. 1999; Schultheiss and Rohde 2002) shape individuals' testosterone levels and, as documented here and elsewhere, these levels in turn interact with social factors in affecting behavior (Josephs et al. 2006). We hope these results suggest the usefulness of incorporating hormonal and other physiological measurement in sociological research, though the vast majority of sociological research questions can be productively studied without regard for this level of analysis.

\section{CONCLUSION}

Because the notion of overcompensation is so common in popular discourse, it may be hard to see that these study results could once have been viewed as counterintuitive. It is not so intuitive, however, for individuals to enact extreme behaviors as a cover for their insecurity. Perhaps the most successful way for men to disguise their masculine insecurity would be to behave in the same way as unthreatened men do. In the present research, this would have resulted in no observed differences between threatened and unthreatened men. Instead, men tend to overcompensate, in a sense overdoing gender, and in so doing inadvertently reveal themselves to be sensitive to threats. One implication of this finding is that extreme masculine behaviors may in fact serve as telltale signs of threats and insecurity. Perhaps those men who appear most assuredly masculine, who in their actions communicate strength, power, and dominance at great levels, may actually be acting to conceal underlying concerns that they lack exactly those qualities they strive to project. 


\section{APPENDIX}

Gender Identity Survey

The gender identity survey given to participants in studies 1,2 , and 4 is printed below (see Bem 1974).

Please answer the questions that follow as well as you can. Do not skip questions. If you are unsure of an answer, please give the answer that seems best to you.

For each of the following words, please pick a number from the following scale that best indicates how well you think the word describes yourself:

Never or Almost Never True 1-2-3-4-5-6-7 Always or Almost Always True

Once you have picked the number that best describes yourself, enter it into the blank next to the word and move on.

\begin{tabular}{ll}
\hline \hline 1. Self-reliant ------- & 2. Yielding ------- \\
3. Helpful ------- & 4. Defends own beliefs -------- \\
5. Cheerful ------- & 6. Moody -------- \\
7. Independent ------- & 8. Shy ------- \\
9. Conscientious ------ & 10. Athletic ------- \\
11. Affectionate ------- & 12. Theatrical ------- \\
13. Assertive ------- & 14. Flatterable ------- \\
15. Happy ------- & 16. Strong personality ------- \\
17. Loyal ------- & 18. Unpredictable ------- \\
19. Forceful ------- & 20. Feminine ------- \\
21. Reliable ------ & 22. Analytical ------- \\
23. Sympathetic ------ & 24. Jealous ------ \\
25. Has leadership abilities ------ & 26. Truthful ------ \\
27. Sensitive to the needs of others ------ & 28. Willing to take risks ------- \\
29. Understanding ------- & 30. Secretive -------- \\
31. Makes decisions easily ------- & 32. Compassionate ------- \\
33. Sincere ------- & 34. Self-sufficient ------- \\
35. Eager to soothe hurt feelings ------- & 36. Conceited ------- \\
37. Dominant ------- & 38. Soft spoken ------- \\
39. Likable ------- & 40. Masculine ------- \\
41. Warm ------- & 42. Solemn ------- \\
43. Willing to take a stand ------- & 44. Tender ------ \\
45. Friendly ------ & 46. Aggressive ------ \\
47. Gullible ------ & 48. Inefficient ------- \\
49. Acts as a leader ------- & 50. Childlike ------- \\
51. Adaptable ------- & 52. Individualistic ------- \\
53. Does not use harsh language ------- & 54. Unsystematic ------- \\
55. Competitive ------- & 56. Loves children ------- \\
57. Tactful ------- & 58. Ambitious ------- \\
59. Gentle ------- & 60. Conventional -------- \\
\hline &
\end{tabular}




\section{American Journal of Sociology}

\section{REFERENCES}

Adams, Henry E., Lester W. Wright Jr., and Bethany Lohr. 1996. "Is Homophobia Associated with Homosexual Arousal?” Journal of Abnormal Psychology 105:440-45.

Adams, Natalie, and Pamela Bettis. 2003. "Commanding the Room in Short Skirts: Cheering as the Embodiment of Ideal Girlhood." Gender and Societv 17:73-91.

Adler, Alfred. (1910) 1956. "Inferiority Feeling and Masculine Protest." Pp. 45-52 in The Individual Psychology of Alfred Adler: A Systematic Presentation in Selections from His Writings, edited by Heinz L. Ansbacher and Rowena R. Ansbacher. New York: Basic Books.

Aiken, Leona S., and Stephen G. West. 1991. Multiple Regression: Testing and Interpreting Interactions. Thousand Oaks, Calif.: Sage.

Anderson, Eric. 2009. Inclusive Masculinity: The Changing Nature of Masculinities. New York: Routledge.

Archer, John. 2006. "Testosterone and Human Aggression: An Evaluation of the Challenge Hypothesis." Neuroscience and Biobehavioral Reviews 30:319-45.

Aronson, Elliot, Phoebe Ellsworth, J. Merrill Carlsmith, and Marti Hope Gonzales. 1990. Methods of Research in Social Psychology, 2d ed. New York: McGraw-Hill.

Baumeister, Roy F., Karen Dale, and Kristin L. Sommer. 1998. "Freudian Defense Mechanisms and Empirical Findings in Modern Social Psychology: Reaction Formation, Projection, Displacement, Undoing, Isolation, Sublimation, and Denial." Journal of Personalitv 66:1081-1124.

Bem, Sandra L. 1974. "The Measurement of Psychological Androgyny." Journal of Consulting and Clinical Psychology 42 (2): 155-62.

Beneke, Timothy. 1997. Proving Manhood: Reflections on Men and Sexism. Berkeley and Los Angeles: University of California.

Bittman, Michael, Paula England, Liana Sayer, Nancy Folbre, and George Matheson. 2003. "When Does Gender Trump Money? Bargaining and Time in Household Work." American Journal of Sociology 109:186-214.

Booth, Allan, Douglas A. Granger, Allan Mazur, and Katie T. Kivlighan. 2006. "Testosterone and Social Behavior." Social Forces 85:167-91.

Bordo, Susan. 1993. Unbearable Weight: Feminism, Western Culture, and the Body. Berkeley and Los Angeles: University of California Press.

Bosson, Jennifer K., Joseph A. Vandello, Rochelle M. Burnaford, Jonathan R. Weaver, and S. Arzu Wasti. 2009. "Precarious Manhood and Displays of Physical Aggression." Personality and Social Psychology Bulletin 35:623-34.

Bradsher, Keith. 2002. High and Mighty: SUVS—The World's Most Dangerous Vehicles and How They Got That Way. New York: Public Affairs.

Brines, Julie. 1994. "Economic Dependency, Gender, and the Division of Labor at Home." American Journal of Sociologv 100:652-88.

Burke, Peter J. 1989. "Gender Identity, Sex, and School Performance." Social Psychology Quarterly 52:159-69.

- 1991. "Identity Processes and Social Stress." American Sociological Review 56: $836-49$.

2004. "Identities and Social Structure: The 2003 Cooley-Mead Award Address." Social Psychology Ouarterlv 67:5-15.

Burke, Peter J., and Jan E. Stets. 2009. Identity Theory. New York: Oxford University Press.

Burke, Peter J., and Judy Tully. 1977. "The Measurement of Role/Identity.” Social Forces 55: 880-97.

Butler, Judith. 1990. Gender Trouble: Feminism and the Subversion of Identity. New York: Routledge.

Carney, Dana R., Amy J. C. Cuddy, and Andy J. Yap. 2010. "Power Posing: Brief Nonverbal Displays Affect Neuroendocrine Levels and Risk Tolerance.” Psychological Science 21:1363-38. 
Carrigan, Tim, Bob Connell, and John Lee. 1985. "Toward a New Sociology of Masculinity." Theorv and Societv 14:551-604.

Christensen, Wendy M., and Myra Marx Ferree. 2008. "Cowboy of the World? Gender Discourse and the Iraq War Debate.” Oualitative Sociology 31:287-306.

Cialdini, Robert B., Richard J. Borden, Avril Thorne, Marcus R. Walker, Stephen Freeman, and Lloyd Reynolds Sloan. 1976. "Basking in Reflected Glory: Three (Football) Field Studies." Journal of Personalitv and Social Psychology 34:366-75.

Cohen, Dov, Richard E. Nisbett, Brian F. Bowdle, and Norbert Schwartz. 1996. "Insult, Aggression, and the Southern Culture of Honor: An 'Experimental Ethnography." Journal of Personality and Social Psychology 70:945-60.

Connell, Robert W. 1983. Which Way Is Up? Essays on Sex, Class, and Culture. Sydney: Allen \& Unwin.

_. 1985. "Masculinity, Violence, and War." Pp. 4-10 in War/Masculinity, edited by Paul Patton and Ross Poole. Melbourne: Intervention.

. 1987. Gender and Power. Stanford, Calif.: Stanford University Press. 1995. Masculinities. Berkeley and Los Angeles: University of California Press.

Connell, Robert W. and James W. Messerschmidt. 2005. "Hegemonic Masculinity: Rethinking the Concept." Gender and Societv 19:829-59.

Dabbs, James M. 1991. "Salivary Testosterone Measurements: Collecting, Storing, and Mailing Saliva Samples." Phvsiologv and Behavior 49:815-17.

Dall'Ara, Elena, and Anne Maass. 2000. "Studying Sexual Harassment in the Laboratory: Are Egalitarian Women at Higher Risk?” Sex Roles 41:681-704.

Ducat, Stephen. 2004. The Wimp Factor: Gender Gaps, Holy Wars, and the Politics of Anxious Masculinity. Boston: Beacon.

Fasteau, Marc F. 1974. The Male Machine. New York: McGraw-Hill.

Freud, Sigmund. (1898) 1962. "The Neuro-Psychoses of Defense." Pp. 43-70 in The Standard Edition of the Complete Psychological Works of Sigmund Freud, vol. 3. London: Hogarth.

Gilmore, David D. 1990. Manhood in the Making. New Haven, Conn.: Yale University Press.

Griffin, Pat. 1998. Strong Women, Deep Closets: Lesbians and Homophobia in Sport. Champaign, Ill.: Human Kinetics.

Heise, David R. 2007. Expressive Order: Confirming Sentiments in Social Actions. New York: Springer.

Johnson, Allan G. 2005. The Gender Knot: Unraveling our Patriarchal Legacy. Philadelphia: Temple University Press.

Josephs, Robert A., Matthew L. Newman, Ryan P. Brown, and Jeremy M. Beer. 2003. "Status, Testosterone, and Human Intellectual Performance: Stereotype Threat as Status Concern." Psychological Science 14:158-63.

Josephs, Robert A., Jennifer G. Sellers, Matthew L. Newman, and Pranjal H. Mehta. 2006. "The Mismatch Effect: When Testosterone and Status Are at Odds." Journal of Personalitv and Social Psychology 90:999-1013.

Jost, John T., Mahzarin R. Banaji, and Brian A. Nosek. 2004. "A Decade of System Justification Theory: Accumulated Evidence of Conscious and Unconscious Bolstering of the Status Quo." Political Psvchologv 25:881-919.

Jost, John T., Jack Glaser, Arie W. Kruglanski, and Frank J. Sulloway. 2003. "Political Conservatism as Motivated Social Cognition." Psychological Bulletin 129: $339-75$.

Jost, John T., and Erik P. Thompson. 2000. "Group-Based Dominance and Opposition to Equality as Independent Predictors of Self-Esteem, Ethnocentrism, and Social Policy Attitudes among African-Americans and European Americans." Journal of Experimental Social Psychology 36:209-32.

Kay, Aaron C., and John T. Jost. 2003. "Complementary Justice: Effects of 'Poor but Happy" and 'Poor but Honest' Stereotype Exemplars on System Justification and Im- 


\section{American Journal of Sociology}

plicit Activation of the Justice Motive." Journal of Personality and Social Psychology 85:823-37.

Kemper, Theodore D. 1990. Social Structure and Testosterone. New Brunswick, N.J.: Rutgers University Press.

Kimmel, Michael S. 1994. "Masculinity as Homophobia: Fear, Shame, and Silence in the Construction of Gender Identity." Pp. 119-41 in Theorizing Masculinities, edited by Harry Brod and Michael Kaufman. Newbury Park, Calif.: Sage. - 1996. Manhood in America: A Cultural History. New York: Free Press.

Kimmel, Michael S., and Matthew Mahler. 2003. "Adolescent Masculinity, Homophobia, and Violence: Random School Shootings, 1982-2001." American Behavioral Scientist 46:1439-58.

Krane, Vikki, Precilla Y. L. Choi, Shannon M. Baird, Christine M. Aimar, and Kerri J. Kauer. 2004. "Living the Paradox: Female Athletes Negotiate Femininity and Muscularity." Sex Roles 50:315-29.

Lieberson, Stanley. 1987. Making It Count: The Improvement of Social Research and Theory. Berkeley and Los Angeles: University of California Press.

Lightdale, Jennifer R., and Deborah A. Prentice. 1994. "Rethinking Sex Differences in Aggression: Aggressive Behavior in the Absence of Social Roles." Personalitv and Social Psychology Bulletin 20:34-44.

Lucas, Jeffrey W. 2003. "Theory Testing, Generalization, and the Problem of External Validity." Sociological Theorv 21:236-53.

Maass, Anne, Mara Cadinu, Gaia Guarnieri, and Annalisa Grasselli. 2003. "Sexual Harassment under Social Identity Threat: The Computer Harassment Paradigm.” Journal of Personalitv and Social Psvchologv 85 (5): 853-70.

Macmillan, Ross, and Rosemary Gartner. 1999. "When She Brings Home the Bacon: Labor-Force Participation and the Risk of Spousal Violence against Women. Journal of Marriage and the Familv 61: 947-58.

Martin, John Levi. 2009. "Formation and Stabilization of Vertical Hierarchies among Adolescents: Towards a Quantitative Ethology of Dominance among Humans." $\underline{\text { So- }}$ cial Psvchology Ouarterlv 72:241-64.

Mazur, Allan, and Allan Booth. 1998. "Testosterone and Dominance." Behavioral and Brain Sciences 21:353-63.

McCall, George J., and J. L. Simmons. 1978. Identities and Interactions. New York: Free Press.

McClosky, Herbert. 1958. "Conservatism and Personality." American Political Science Review 52:27-45.

McCloskey, Lann A. 1996. "Socioeconomic and Coercive Power within the Family." Gender and Societv 10:449-63.

Mehta, Pranjal H., Amanda C. Jones, and Robert A. Josephs. 2008. "The Social Endocrinology of Dominance: Basal Testosterone Predicts Cortisol Changes and Behavior following Victory and Defeat." Journal of Personality and Social Psychology. 94:1078-93.

Messerschmidt, James W. 2010. Hegemonic Masculinities and Camouflaged Politics: Unmasking the Bush Dynasty and Its War against Iraq. Boulder, Colo.: Paradigm.

Munsch, Christin, and Robb Willer. 2012. "The Role of Gender Identity Threat in Perceptions of Date Rape and Sexual Coercion." Violence against Women. 18(10): 1125-46.

Newman, Matthew L., Jennifer G. Sellers, and Robert A. Josephs. 2005. "Testosterone, Cognition, and Social Status." Hormones and Behavior 47:205-11.

Pascoe, C. J. 2005. "'Dude, You're a Fag': Adolescent Masculinity and the Fag Discourse." Sexualities 8:329-46.

Pratto, Felicia, James Sidanius, Lisa M. Stallworth, and Bertram F. Malle. 1994. "Social Dominance Orientation: A Personality Variable Predicting Social and Political Attitudes." Journal of Personality and Social Psvchology 67:741-63. 
Putnam, Robert D. 2000. Bowling Alone: The Collapse and Revival of American Community. New York: Simon \& Schuster.

Ridgeway, Cecilia L. 2011. Framed by Gender: How Gender Inequality Persists in the Modern World. New York: Oxford University Press.

Ross, Lee, Mark R. Lepper, and Michael Hubbard. 1975. "Perseverance in SelfPerception and Social Perception: Biased Attributional Processes in the Debriefing Paradigm." Journal of Personalitv and Social Psvchology 32:880-92.

Rowe, Richard, Barbara Maughan, Carol M. Worthman, E. Jane Costello, and Adrian Angold. 2004. "Testosterone, Antisocial Behavior, and Social Dominance in Boys: Pubertal Development and Biosocial Interaction." Biological Psychiatry 55:546-52.

Salimetrics, LLC. 2010. Expanded Range Salivary Testosterone Enzyme Immunoassay Kit. State College, Pa.: Salimetrics, LLC.

Schrock, Douglas, and Michael Schwalbe. 2009. "Men, Masculinity, and Manhood Acts." Annual Review of Sociology 35:277-95.

Schultheiss, Oliver C., Kenneth L. Campbell, and David C. McClelland. 1999. "Implicit Power Motivation Moderates Men's Testosterone Response to Imagined and Real Dominance Success." Hormones and Behavior 36:234-41.

Schultheiss, Oliver C., and Wolfgang Rohde. 2002. "Implicit Power Motivation Predicts Men's Testosterone Changes and Implicit Learning in a Contest Situation." $\underline{\text { Hormones }}$ and Behavior 41:195-202.

Sidanius, Jim, and Felicia Pratto. 1999. Social Dominance: An Intergroup Theorv of Social Hierarcy and Oppression. New York: Cambridge University Press.

Sidanius, Jim, Felicia Pratto, and Lawrence Bobo. 1996. "Racism, Conservatism, Affirmative Action, and Intellectual Sophistication: A Matter of Principled Conservatism or Group Dominance?" Journal of Personality and Social Psychology 70:476-90.

Stanton, Steven J., Jacinta C. Beehner, Ekjyhot K. Saini, Cynthia M. Kuhn, and Kevin S. LaBar. 2009. "Dominance, Politics, and Physiology: Voters' Testosterone Changes on the Night of the 2008 United States Presidential Election." PLoS One 4 (10): e7543.

Stets, Jan E. and Peter J. Burke. 2000a. "Femininity/Masculinity." Pp. 997-1005 in Encyclopedia of Sociology, rev. ed. Edited by Edgar F. Borgatta and Rhonda J. V. Montgomery. New York: Macmillan.

. 2000b. "Identity Theory and Social Identity Theory." Social Psvchologv Ouarterlv 63:224-37.

Stryker, Sheldon. 1980. Symbolic Interactionism: A Social Structural Version. Menlo Park, Calif.: Cummings.

Terburg, David, Henk Aarts, and Jack van Honk. 2012. "Testosterone Affects Gaze Aversion from Angry Faces outside of Conscious Awareness." Psychological Science 23:459-63.

Trumble, Benjamin C., Daniel Cummings, Christopher von Rueden, Kathleen A. O'Connor, Eric A. Smith, Michael Gurven, and Hillard Kaplan. 2012. "Physical Competition Increases Testosterone among Amazonian Forager-Horticulturalists: A Test of the 'Challenge Hypothesis.'” Proceedings of the Roval Societv of London B: Biological Sciences 279:2907-12.

Ussher, Jane M. 1997. Fantasies of Femininity: Reframing the Boundaries of Sex. New Brunswick, N.J.: Rutgers University Press.

Vandello, Joseph, Jennifer K. Bosson, Dov Cohen, Rochelle M. Burnaford, and Jonathan R. Weaver. 2008. "Precarious Manhood." Journal of Personalitv and Social Psvchology 95:1325-39.

van Honk, Jack, Adriaan Tuiten, Rien Verbaten, Marcel van den Hout, Hans Koppescaar, Jos Thijssen, and Edward de Haan. 1999. "Correlations among Salivary Testosterone, Mood, and Selective Attention to Threat in Humans." Hormones and Behavior 36:17-24. 


\section{American Journal of Sociology}

Watson, David, Lee Anna Clark, and Auke Tellegen. 1988. "Development and Validation of Brief Measures of Positive and Negative Affect: The PANAS Scales." Journal of Personalitv and Social Psychology 54:1063-70.

Weinstein, Netta, William S. Ryan, Cody R. DeHaan, Andrew K. Przybylski, Nicole Legate, and Richard M. Ryan. 2012. "Parental Autonomy Support and Discrepancies between Implicit and Explicit Sexual Identities: Dynamics of Self-Acceptance and Defense." Journal of Personalitv and Social Psychology 102:815-32.

West, Candace, and Don H. Zimmerman. 1987. "Doing Gender." Gender and Societv $1: 125-51$.

Willer, Robb, Ko Kuwabara, and Michael W. Macy. 2009. "The False Enforcement of Unpopular Norms." American Journal of Sociology 115:451-90.

Wilson, Marc S. 2005. "Gender Group Identity as a Moderator of Sex Differences in Interpersonal and Intergroup Dominance." Pp. 145-67 in Psychology of Gender Identity, edited by Janice W. Lee. New York: Nova.

Wingfield, John C., Robert E. Hegner, Alfred M. Dufty Jr., and Gregory F. Ball. 1990. "The 'Challenge Hypothesis': Theoretical Implications for Patterns of Testosterone Secretion, Mating Systems, and Breeding Strategies." American Naturalist 136: 829-46.

Zaller, John. 1991. "Information, Values, and Opinions." American Political Science Review 85:1215-37. 